\title{
EX-vivo Expansion of Muscle-Regenerative Cells for the Treatment of Muscle Disorders
}

\author{
Schaaf $\mathrm{G}^{1 * \#}$, Sage $\mathrm{F}^{2 \#}$, Stok $\mathbf{M}^{3}$, Brusse $\mathrm{E}^{4}$, Pijnappel WWM${ }^{1}$, Reuser $\mathrm{AJ}^{1}$ and vd Ploeg $\mathrm{AT}^{1}$ \\ ${ }^{1}$ Department of Pediatrics and Department of Clinical Genetics, Center for Lysosomal and Metabolic Diseases, Erasmus MC University Medical Center, Dr. \\ Molewaterplein 50, $3015 \mathrm{GE}$, The Netherlands \\ ${ }^{2}$ Department of Cell Biology, Stem Cell Institute, Erasmus MC University Medical Center, The Netherlands \\ ${ }^{3}$ Department of Hematology, Erasmus MC University Medical Center, The Netherlands \\ ${ }^{4}$ Department of Neurology, Center for Lysosomal and Metabolic Diseases, Erasmus MC University Medical Center, The Netherlands \\ \#Contributed equally
}

\begin{abstract}
Skeletal muscle has an impressive regenerative potential. The cells that mediate muscle repair have unique properties that are not restricted solely to the formation of new muscle, but also contribute to the repair of damaged residual tissue. Recent studies have shown that freshly isolated muscle-regenerative cells maintain these properties, and contribute to muscle repair after transplantation to host muscle tissue. Muscle-regenerative cells are typically present in low numbers, and the yield of therapeutic cells from biopsies is low. Ex-vivo expansion of the candidate cells is therefore required. However, when cultured in vitro, the muscle-regenerative cells, and particularly muscle satellite cells, lose their regenerative capacities. This poses a major limitation on the introduction of cell-based therapies for muscle disorders. Here, we take the opportunity to review the promise of cell-based therapies specifically for the treatment of degenerative muscle diseases. We focus particularly on optimizing the conditions for expanding the cells in vitro in a way that maintains their regenerative properties.
\end{abstract}

Keywords: Muscle regenerative cells; Muscle disorders; Self renewal

\section{Introduction}

Muscle disorders are a group of inherited or acquired diseases with a great variety of disease manifestations. Their common denominator is progressive loss of muscle structure and function, for which no sufficient therapy is currently available.

Cell transplantation and stem-cell-based therapies are emerging therapies. Cell-based therapies were established with the use of bonemarrow transplantations, which were performed for the first time in 1968 [1]. Various clinical trials (http://clinicaltrials.gov) have studied the potential of allogeneic stem cells such as mesenchymal stem cells, human embryonic stem-cell (hESC)-derived stem cells and hematopoietic stem cells for treating a range of conditions. Particularly exciting in this respect is the first in-man clinical trial to evaluate neural stem cells for use in patients who have suffered a stroke (a study by ReNeuron; http://www.reneuron.com), which is currently in progress. These developments indicate that the field of cell-based therapies is expanding and that expectations are high.

Cell-based therapies have been considered for the treatment of muscular dystrophies ever since the injection of myoblasts into a mouse model for Duchenne Muscular Dystrophy (MDX mice) resulted in the generation of dystrophin positive myofibers [2-4]. The initial excitement was dampened by observations that, due to poor survival, immune rejection and the limited bio-distribution of transplanted cells, the regenerative effects were both modest and transient. The field was re-ignited by the identification of muscle-regenerative cells other than myoblasts - i.e. satellite cells, pericytes and muscle-derived stem cells with superior engraftment potential. Recent studies in animal models have shown that, upon transplantation, several muscle stem-cell populations do indeed retain their unique regenerative properties [5-7]. This sets the scene for their clinical exploration. The potential of some of the muscle-regenerative cells such as mesangioblasts is currently being evaluated in clinical trials - a development that indicates the progress in the field. Several recent reviews have extensively evaluated the properties of the different muscle-regenerative cell types [8-11].

The inherited muscle disorders show general involvement of skeletal muscles, often with a limb-girdle distribution, indicating both that several muscle groups need to be targeted and that considerable numbers of donor cells are required. It remains an important practical limitation that the candidate populations can often be obtained only in small numbers, and that expansion of these populations is required to obtain these cells in clinically relevant numbers. A potential advantage of using cultured therapeutic cells is that they might offer an opportunity to correct the disease-causing genetic defect before injection, potentially opening the way for the development of an autologous cell-based therapeutic approach. Furthermore, autologous stem/regenerative cells will greatly reduce the risk of immune rejection that limited the success of earlier muscle-cell transplantation strategies. However, two major concerns are associated with the culture of therapeutic cells: the loss of regenerative potential and the acquisition of genomic instability. If the development of cell-based therapies is to be successful, these considerations should be taken into account.

In this review, we highlight several types of muscle-regenerative cells with distinct properties and focus on recent approaches and advances

*Corresponding author: Schaaf G, Department of Pediatrics and Dept of Clinical Genetics, Center for Lysosomal and Metabolic Diseases, Erasmus MC University Medical Center, Dr. Molewaterplein 50, 3015 GE, The Netherlands, E-mail: g.schaaf@erasmusmc.nl

Received August 21, 2012; Accepted October 15, 2012; Published October 17, 2012

Citation: Schaaf G, Sage F, Stok M, Brusse E, Pijnappel WWM, et al. (2012) Ex-vivo Expansion of Muscle-Regenerative Cells for the Treatment of Muscle Disorders. J Stem Cell Res Ther S11:003. doi:10.4172/2157-7633.S11-003

Copyright: @ 2012 Schaaf G, et al. This is an open-access article distributed unde the terms of the Creative Commons Attribution License, which permits unrestricted use, distribution, and reproduction in any medium, provided the original author and source are credited. 
in the expansion of muscle stem or progenitor cells. The systematic application of these strategies will be essential to exploring the further clinical application of these exciting new treatment modalities.

\section{Skeletal Muscle Disorders and Muscle Regeneration}

\section{Muscle disorders}

Skeletal muscle comprises the body's largest tissue, accounting for about $40 \%$ of total body weight, and playing critical roles in movement, respiration, stabilization of the skeleton, glucose homeostasis, and thermoregulation. It consists of bundles of multinucleated, elongated membrane-bound cells, called muscle fibers. These fibers contain bundles of myofibrils showing a striated pattern of repeating units, known as sarcomeres, which are the fundamental contractile units of skeletal muscle. The myofibrils set off a mechanical contraction in response to neuronal or electrical stimuli, generating the contractile force needed by a particular skeletal muscle to perform its function. Adult skeletal muscle also houses several populations of stem cells, which play important roles in maintaining the integrity of the tissue and mediating the repair of any damage to the muscle. As we discuss below, satellite cells comprise the predominant muscle stem cell population responsible for postnatal muscle regeneration [12].

Acute or chronic muscle damage results from the disruption of the structural organization of the muscle, inducing muscle-fiber necrosis, infiltration of inflammatory cells, and the deposition of non-myogenic material (e.g. connective tissue, fat, and/or glycogen deposits). Many hereditary and acquired neuromuscular disorders - including the muscular dystrophies, toxic, inflammatory and metabolic myopathies, and neuropathies leading to muscle denervation - are associated with muscle damage. Muscle damage is also seen in systemic conditions such as ageing, cancer and endocrinological disorders. The neuromuscular disorders are a heterogeneous group of rare disorders that may present at any age and may significantly reduce life-expectancy, especially when the cardiac and respiratory muscles are involved (such as in Duchenne Muscular Dystrophy (DMD) and Pompe's Disease).

Muscle disorders are associated with a lengthening list of defects in genes that encode cytoskeletal, lysosomal, sarcomeric and membraneassociated proteins. The clinical and pathophysiological hallmarks of these myopathies can vary widely and are beyond the scope of this review (interested readers are referred to the specific literature; see for instance [13-15]). However, irrespective of the mechanisms involved, the common denominator is a muscle-wasting phenotype. With regard to several of the inherited muscular dystrophies (Table 1 ), it is thought that disease progression is determined largely by exhaustion of the stem-cell pool and the resulting progressive loss of muscle-regeneration potential. On the basis of this assumption, it is possible that the attenuation of muscle damage or the restoration of the muscle-regenerative potential is key to the effective treatment of neuromuscular disorders.

\section{Muscle regeneration in healthy and diseased muscle}

Minor damage to the muscle fibers is patched by the family of dysferlin proteins [48], while more extensive injury results in the activation of muscle-resident stem cells that marks the initiation of the regenerative response. Recent studies have shown that adult muscle regeneration depends mainly on one population of stem cells, the satellite cells (SCs) (Figure 1) [49-51]. Upon sustaining damage, the activated SCs start to proliferate and generate committed myoblasts, which differentiate into myocytes. To repair the damage, these myocytes fuse with each other to make new myofibers, or fuse with the residual myofiber (Figure 1).

While the repair process in healthy muscle is completed within one to three weeks, depending on the extent of the damage, the regenerated muscle fibers of dystrophic muscle remain unstable due to the underlying genetic defects, and continue to accumulate damage. As a result, dystrophic muscle engages in continuous rounds of degeneration and SC activation. These ongoing cycles of muscle degeneration and regeneration characterize dystrophic muscle, and are thought to result in exhaustion of the SC pool (discussed further below) which progresses to loss of function of the affected muscle and, eventually, to muscle atrophy. It is unclear whether ongoing muscle regeneration occurs during the disease progression of all muscle disorders (such as facioscapulohumeral dystrophy; FSHD). But even for conditions in which mainly atrophy has been observed (and loss of SCs is not implied), the affected muscles will have reduced regenerative potential, and muscle wasting will be progressive.

It has been proposed that muscle is capable of complete regeneration when SC numbers are at least $10-20 \%$ of those in young adults [52]. This may indicate that the numbers of regenerative-competent SCs decrease below the critical threshold during disease progression, which may imply that even a modest increase in stem-cell numbers would have a beneficial effect in diseased muscle. This observation may provide a basis for cell therapy of muscle disorders using muscle-regenerative cells.

\section{Mechanisms of satellite-cell exhaustion}

Postnatal muscle growth and regeneration is mediated by muscle satellite cells, which characteristically reside beneath the basal lamina and were first described over fifty years ago by Alexander Mauro [53]. Recently, to celebrate their discovery, excellent reviews on them [12,54] have been published. SCs are characterized by the expression of the paired box transcription factor Pax7 across species, including man, mouse and chicken [54]. Several recent studies have shown that SCs are bona-fide stem cells [55] and generate both differentiating progeny (myoblasts and myocytes) and, in a process called self-renewal, new SCs. As stated above, muscle regeneration does not proceed in the absence of SCs [49-51] and loss of SC numbers or activity is thought to be at the basis of the muscle-wasting that is observed in the diverse conditions affecting skeletal muscle. There may be several mechanisms, both cell-intrinsic and -extrinsic, underlying SC exhaustion in dystrophic muscle and here we will discuss several of the mechanisms that have been proposed.

In some hereditary myopathies, the association between the gene defect and SCs exhaustion is very clear. In these cases, the 'disease' gene is normally expressed in SCs in healthy individuals; the absence or loss of function of this gene directly affects SC function. For instance, lamin A/C deficiency in Emery-Dreifuss myopathies induces premature SC differentiation and cell-cycle exit [38] (Table 1). As a result, the SC pool is depleted and muscle-regenerative potential progressively lost.

Other disease-causing genes, such as dystrophin, are not expressed in the SC compartment, but only in the terminally differentiated myofibers. While loss of function of these genes is directly related to myofiber stress and damage, the lack of expression of these genes does not directly affect SC behavior. In these cases, the progressive musclewasting alters the architecture of the muscle in a process that may involve inflammation, fibrosis or deposition of non-myogenic material, as has been described for DMD $[35,56]$. As SCs reside in a specialized 
Citation: Schaaf G, Sage F, Stok M, Brusse E, Pijnappel WWM, et al. (2012) Ex-vivo Expansion of Muscle-Regenerative Cells for the Treatment of Muscle Disorders. J Stem Cell Res Ther S11:003. doi:10.4172/2157-7633.S11-003

Page 3 of 15

\begin{tabular}{|c|c|c|c|}
\hline Disease & Gene $^{1}$ & Animal model ${ }^{2}$ & SC exhaustion ${ }^{3}$ \\
\hline \multicolumn{4}{|l|}{ Inherited muscular dystrophies } \\
\hline Becker Muscular Dystrophy & Dystrophin (Xp21) & MDX mouse [16], mild phenotype & $\begin{array}{l}\text { Indirect: Functional change: extensive } \\
\text { activation; change in environment [35] }\end{array}$ \\
\hline \multirow[t]{4}{*}{ Congenital Muscular Dystrophy } & Laminin A2/Merosin (6q22-6q23) & Laminin A2-deficient mouse [17] & \\
\hline & Integrin A7 (12.q13.2) & Integrin A7-deficient mouse [18] & $\begin{array}{l}\text { Indirect? Changes in environment (loss } \\
\text { of integrin A7) [36] }\end{array}$ \\
\hline & Fukutin (9q31-q33) & Fukutin chimeric mouse [19] & \\
\hline & SEPN1 (1p36) & SEPN1-deficient mouse [20] & Direct: increased proliferation SCs [37] \\
\hline Duchenne Muscular Dystrophy & Dystrophin (Xp21) & MDX mouse [16]; GRMD dogs [21] & $\begin{array}{l}\text { Indirect: Functional change: extensive } \\
\text { activation; change in environment [35] }\end{array}$ \\
\hline \multirow[t]{2}{*}{ Emery-Dreifuss } & Emerin (Xq28) & Emerin-deficient mouse [22] & $\begin{array}{l}\text { Direct: Premature differentiation/cell } \\
\text { cycle exit [38] }\end{array}$ \\
\hline & Lamin A/C (1q11-q21) & Lamin a-deficient mouse [23] & \\
\hline $\begin{array}{l}\text { Facioscapulohumeral Muscular } \\
\text { Dystrophy }\end{array}$ & $\begin{array}{l}\text { FSHMD1A, D4Z4 contraction (95\%; } \\
4 q 35)\end{array}$ & FRG-1 transgenic mouse [24] & $\begin{array}{l}\text { Direct and indirect: Increased apoptosis } \\
\text { of myoblast/inhibition of differentiation } \\
{[39,40]}\end{array}$ \\
\hline \multirow[t]{3}{*}{ Limb-Girdle Muscular Dystrophy } & Dysferlin (2p13.2) & Dysferlin-deficient mouse [25] & Indirect: Inhibition of myoblast fusion [41] \\
\hline & Alpha-sarcoglycan (17q12- 21.33) & BIO 14.6 hamster [26] & \\
\hline & POMT1 (9q34.1) and POMT2 (14q24.3) & $\begin{array}{l}\text { POMT1-deficiency in mouse is } \\
\text { embryonic letal [27] }\end{array}$ & $\begin{array}{l}\text { Indirect; apoptosis in droshophila } \\
\text { myoblasts [42] }\end{array}$ \\
\hline \multirow[t]{2}{*}{ Myotonic Dystrophy } & DMPK (DM1; 19q13.2-q13.3) & DMPK-deficient mice [28] & $\begin{array}{l}\text { Indirect: myoblast dysfunction was } \\
\text { reported [43] }\end{array}$ \\
\hline & ZNF9 (DM2; 3q21) & ZNF9+/- mouse [29] & \\
\hline Oculopharyngeal Muscular Dystrophy & PABPN1 (14q) & $\begin{array}{l}\text { Transgenic mouse expressing mutated } \\
\text { PABPN1 [30] }\end{array}$ & $\begin{array}{l}\text { Direct and indirect: defects in myoblast } \\
\text { differentiation and proliferation [44] }\end{array}$ \\
\hline \multicolumn{4}{|l|}{ Metabolic Myopathies } \\
\hline Pompe's Disease & Acid Alpha-Glucosidase (17q25.2-q25.3) & GAAKO mouse $[31,32]$ & $\begin{array}{l}\text { Unknown: Increased SC activation } \\
\text { reported [45] }\end{array}$ \\
\hline \multicolumn{4}{|l|}{ Other } \\
\hline Stress Urinary incontinence ${ }^{4}$ & Ageing & Models reviewed by [33] & $\begin{array}{l}\text { Indirect: Age-related loss of replicative } \\
\text { potential, apoptosis) [46] }\end{array}$ \\
\hline $\begin{array}{l}\text { Chronic Obstructive Pulmonary Disease } \\
\text { (COPD) }\end{array}$ & Alpha-1 Antitrypsin (14q32.1) & Klotho knockout [34] & $\begin{array}{l}\text { Indirect: replicative senescence/ } \\
\text { reduction minimal telomere length [47] }\end{array}$ \\
\hline
\end{tabular}

$1=$ Genes involved in disease; human gene locus between brackets, for some syndromes more genes were implicated and are indicated in a new row

2=Examples of animal models, mainly mouse, are listed. The selected models were reported to give a relevant phenotype, unless indicated otherwise. References are shown between brackets

3=Exhaustion of SC pool may be direct (gene expressed and has critical function in SC) or indirect (gene not expressed in SC). Adapted from Morgan and Zammit Exp. Cell. Res (2010) 316: 3100-3108 [164]; Relevant references for SC exhaustion are shown between brackets

Table 1: Muscle disorders with indication of SC exhaustion. The table lists a number of muscle disorders with indications of satellite cell (SC) exhaustion. SC exhaustion may be direct if the gene is expressed in SC pool and affects the function of SCs. The effect of the gene defect may be indirect if the gene is normally not expressed by SCs. The disease causing genes and relevant animal models are listed.

niche formed by the basal lamina covering them, their functioning and survival is dependent on the availability of this niche. The detrimental changes to the muscle architecture inhibit the potential of SCs to regenerate the muscle, or even induce the death of SCs.

The importance of the SC environment in determining the muscle regenerative response has also become clear from heterochronic transplantation studies. These studies showed that the age of the host determines the efficiency of the muscle-regenerative response [57]. Aged muscle progenitors were capable of efficient muscle regeneration when transplanted into a young host. More recent findings using a heterochronic parabiosis approach further substantiated these early findings and showed that circulating factors play key roles in determining the regenerative potential of aged SCs [57-60]. The progressive apoptosis of SCs observed in stress urinary incontinence (SUI), which is an age-related myopathy, has been proposed to result from a changing (ageing) environment [46] and would be supporting the findings in the (parabiotic) mouse studies. In conclusion, changes in the availability of 'regenerative factors' in the aged or diseased environment (either niche or circulating factors) limit an adequate regenerative response of SCs and contribute to functional and numerical loss of SCs.

As a third mechanism of SC exhaustion excessive activation/ proliferation of the SC pool has been proposed, such as for instance in DMD [61] and chronic obstructive pulmonary disease (COPD) [47] (Table 1). As stated above, some dystrophies and muscle-wasting conditions are characterized by continuous cycles of degeneration and regeneration, and lead to excessive use of muscle SCs. This is thought to induce replicative stress and is attributed to telomere erosion $[62,63]$ or oxidative stress [64]. As a result, the SC pool becomes progressively depleted. The association of replicative stress by telomere erosion with the dystrophic phenotype is underscored by findings in the mouse model of Duchenne Muscular Dystrophy, the MDX model. Relative to human patients, MDX animals have a very mild phenotype and a nearnormal lifespan. However, using MDX/mTRnull (mTR= telomerase RNA component Terc) compound mouse model, the authors showed that loss of telomere maintenance exacerbated the phenotype of the MDX mouse, more closely mimicking the disease progression observed in human patients. The study of Sacco et al. [7] found the 


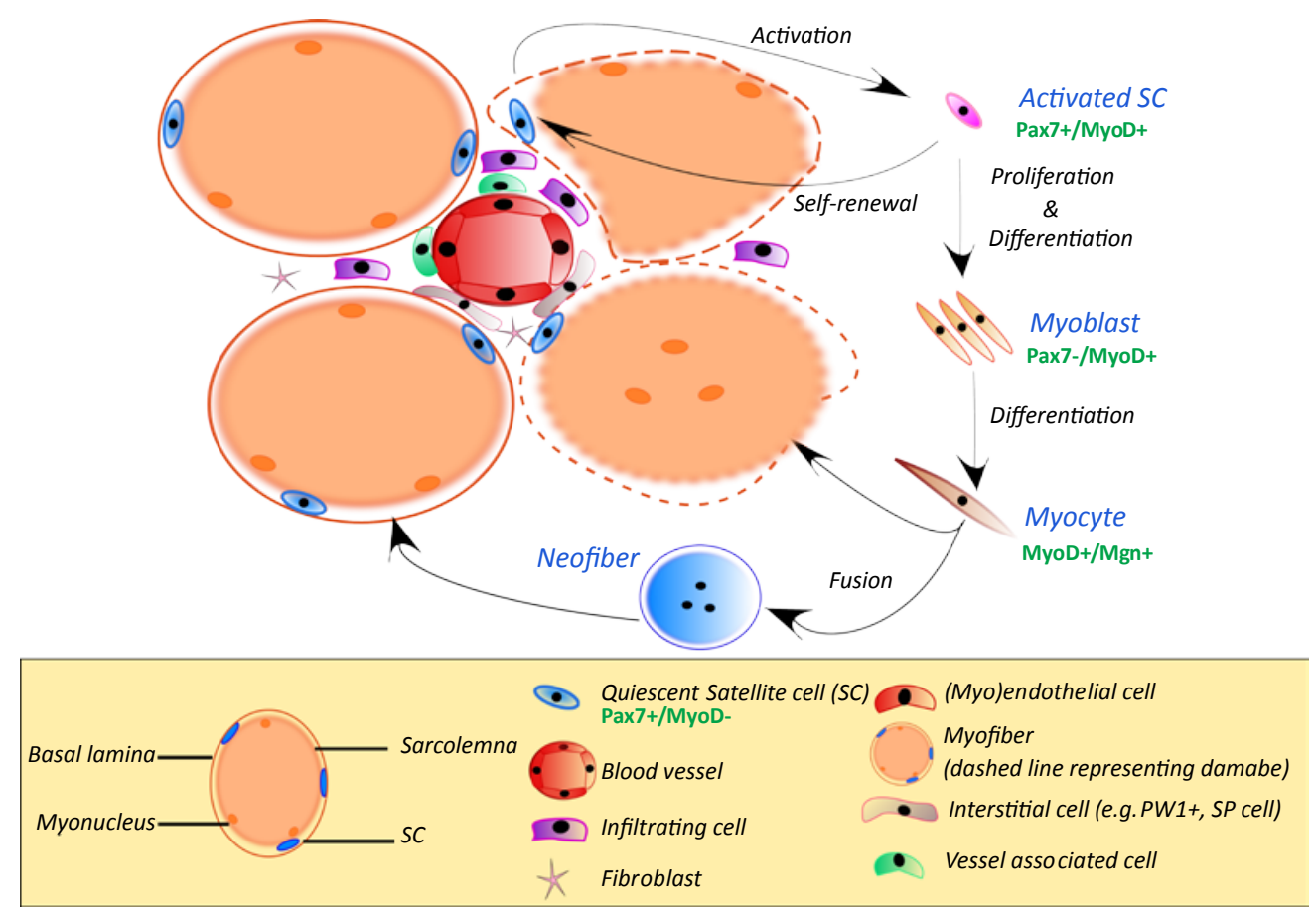

Figure 1: Skeletal muscle regeneration and muscle resident stem cells. The figure depicts a cross-section of skeletal muscle showing myofibers surrounding a blood vessel and the localization of several types of muscle-resident stem cells. The satellite cells (SCs) are located at the periphery of the myofibers, beneath the basal lamina, and become activated upon damage. The activated SCs start expressing myogenic factors, including MyoD and progress to become myoblasts. Myoblasts upregulate the expression of the differentiation factor myogenin (Mgn) and differentiate into myocytes that finally fuse together (forming neofibers) or to damaged myofibers. The figure is adapted from Kuang et al. [114] Trends Mol Med 14: 82-91.

function of the SC population to be compromised and the SC pool to become depleted with disease progression. Myoblasts isolated from the MDX/mTRnull mice were also found to have significantly shorter telomeres. Taken together, these findings suggest that loss of telomere length and replicative stress contribute to the muscle pathology in DMD [63]. A recent study on a modest number of patients found reduced minimal telomere length in limb muscle from COPD patients, resulting in an exhausted muscle regenerative capacity and a musclewasting phenotype [47]. This indicates that exhaustion of the SC pool through excessive proliferation is not only restricted to DMD, but may contribute to loss of muscle function and mass in other muscle disorders as well.

\section{Cell-based Therapies}

\section{Therapy of muscle disorders}

There are currently few treatment options for muscle disorders. One of the few myopathies for which a relatively effective treatment modality is available is Pompe's disease. Patients with this disease develop skeletal muscle pathology due to storage of glycogen in the lysosomes caused by acid $\alpha$-glucosidase (GAA) deficiency. The clinical symptoms of Pompe's disease can manifest at any age [65]. Patients of all ages receive enzyme replacement therapy (ERT). The rapid demise of infants with symptoms presenting at birth is prevented by correction of their cardiac hypertrophy and by the maintenance of their pulmonary function. Most treated infants acquire sitting and walking abilities while they would have had a life expectancy of less than 1 year if untreated [66]. Patients with later onset and less progressive forms of Pompe's disease benefit from enzyme replacement therapy and show improved walking capacity and stabilization of pulmonary function [67]. Recent results suggest that ERT in these patients also prolongs survival (Gungor/ van der Ploeg, personal communication). Despite the success of this treatment, a number of limitations are associated with ERT -including poor responder patients, development of resistance to ERT and the high treatment costs - thus explaining the need for novel treatments.

For most of the other muscle disorders, no treatments are currently available and most approaches offer palliative care. However, some of the treatments that are in use, such as for instance glucocorticoid treatment for DMD, actually attenuate disease progression. Glucocortoid treatment slows down the loss of muscle strength, prolongs ambulation, and supports respiration [68] and even though suboptimal is currently the standard treatment for DMD [69].

Some experimental therapies (such as exon skipping for DMD [70] (e.g. clinical trial identifier NCT00159250)) have reached the clinical trial phase, and the hope of a positive outcome is high. Inherited muscular diseases are promising targets for gene-therapy strategies: in most cases, the etiology of the disease involves a single gene (so-called single-gene disorders).

Cell therapy for the treatment of muscle disorders is one alternative being considered as an alternative to ERT, gene therapy or other experimental approaches. Its promise is discussed below.

\section{Rationale for the use of muscle stem cells in the treatment of muscle disorders}

Cell-based therapies are particularly promising for the treatment of muscle disorders, as they would enable the robust regenerative properties of muscle-regenerative cells to be exploited. Muscle- 
regenerative cells are attractive for therapy for three reasons: their ability to generate new myofibers, to repair damaged myofibers, and to correct the genetic defect through cellular fusion. The ability to fuse and share genetic material with the regenerated myofibers is an inherent programmed activity of muscle-regenerative cells and is restricted to muscle regeneration. When cells from healthy donors are used, or when gene-corrected autologous cells are used, this property can be employed to restore expression of the disease-causing genes.

In addition to these properties, most of the cell types that are considered for muscle-regenerative purposes (see below) replenish the stem-cell pool. As discussed above, exhaustion of the endogenous stem cell pool is thought to contribute to the muscle-wasting phenotype that is common to a subset of muscle disorders. The self-renewing transplanted cells continue to be recruited during ongoing cycles of regeneration and expand the regenerated area. Over time, the condition of the transplanted muscles improves, potentially restoring the function of the affected muscles.

Based on these properties, we and others hypothesize that the use of cells with myogenic potential may make it possible to arrest or attenuate the muscle-wasting process that is common to all myopathies.

\section{Several donor cell types as a source of muscle stem-cell therapy}

Skeletal muscle is known to harbor several populations of stem cells; including satellite cells [53,55], interstitial cells [71] and vesselassociated cells [72], and novel candidates continue to be identified. The predominant muscle-resident stem cells are the satellite cells (SCs), which recent independent studies have shown to be mainly responsible for postnatal muscle growth and regeneration [49-51]. It is still unclear whether the non-SC populations are involved in the physiological and pathophysiological repair of adult muscle, and, if so, which role they play. As vessel-associated cells have been shown to contribute to the SC pool early in postnatal life [6], it has been suggested that a subset of the non-SC population are SC progenitors [73]. But as SC populations $[5,7]$ and non-SC populations [71,72] both display potential to regenerate muscle and replenish the endogenous SC pool upon transplantation $[6,74,75]$, both qualify as significant candidate donor-cell populations for cell therapy.

The various muscle-regenerative cells have different properties, and ideally the candidate donor cells should comply with the following features:

- They should have a robust muscle-regenerative potential

- The cells should have the potential to expand ex-vivo while maintaining their regenerative properties

- They should contribute to the stem-cell population and replenish the SC pool

- They should induce minimal immunogenicity

- The cells should have the potential to be delivered systemically, although cells delivered locally may be clinically relevant.

We discuss these guidelines for two candidate cell populations with distinct properties: cells with the highest myogenic potential after local delivery (myoblasts/satellite cells), and cells that can regenerate muscle after systemic delivery (vessel-associated cells). The properties of other muscle-regenerative cells are summarized in table 2.

To illustrate their clinical potential the two selected cell types are described only briefly. For a much more detailed discussion of the properties and clinical potential of the different muscle-regenerative cells readers are referred to several recent reviews [10,11,76,77].

\section{Muscle stem cells for local delivery: myoblasts/satellite cells}

The myogenic lineage constitutes different cell populations with distinct phenotypical and functional properties. SCs (Pax7-expressing cells in the mouse) (Figure 1) are the predominant muscle-resident stem-cell population and are capable of proliferation and self-renewal. Upon activation, SCs enter the cell cycle and progress to become myoblasts (pax7-/myod+) (Figure 1), which represent committed progenitors [86]. Equipped with limited self-renewal, but extensive differentiation potential, myoblasts, undergo a limited number of divisions before differentiating into myocytes (Figure 1). Myocytes are differentiated muscle cells that have upregulated myogenin and are programmed to fuse either with each other (thereby forming neofibers) or with damaged myofibers.

On the basis of their extensive proliferation and differentiation potential in vitro, myoblasts have long been considered for muscle cell-therapy. Initially, very promising results were produced by using myoblasts as donor cells for transplantation purposes (Myoblast Transfer Therapy; MTT) [4], but subsequent studies revealed a number of obstacles that complicated their introduction into the clinic. These included poor survival, immune rejection, and limited migration of the donor cells $[87,88]$.

It was hypothesized that muscle stem cells, SCs, would have greater regenerative potential, and recent studies have indeed demonstrated the remarkable muscle-regenerative potential of freshly isolated SCs $[5,7,75]$, which succeeded in repopulating muscle even after transplantation of a single SC [7]. After transplantation into muscle of MDX hosts, SCs were shown to restore dystrophin expression [5]. This also restored interest in the therapeutic potential of myogenic cells. As well as contributing to muscle regeneration, transplanted SCs were shown to give rise to new SCs $[5,7,75]$, indicating that SCs retain the potential to self-renew upon transplantation. Recently this selfrenewal capacity was further demonstrated in a serial transplantation assay [75], which is currently the most stringent assay for showing selfrenewal potential.

Unlike myoblasts, SCs appear to have low immunogenicity. Cerletti and colleagues have shown that healthy SCs transplanted into the muscle of immune-competent MDX mice resulted in robust donorcell engraftment and contribution to the formation of host-donor chimaeric myofibes that lasted up to 4 months after transplantation [5]. The authors even reported reduced inflammation of the host muscle, indicating that the transplanted cells did not generate a strong immune response

Despite their promising regenerative potential, SCs share a major limitation: their low migratory potential. SCs and myoblasts therefore have limited or no ability to engraft after systemic delivery, while a contribution to muscle regeneration following intramuscular injection is often observed only in the proximity of the injection site. Recently, this was also verified for systemically delivered human muscle progenitors (i.e. SC-derived myoblasts) that failed to engraft in dystrophic muscle [72]. The same study showed that the human muscle progenitors contributed robustly to muscle regeneration after intramuscular injection.

Taken together, the properties of SCs, and, to a lesser extent, of myoblasts, are most suitable for the treatment of disorders affecting 


\begin{tabular}{|c|c|c|c|c|c|c|c|}
\hline Donor cell type & Primary location & \begin{tabular}{|l|}
$\begin{array}{l}\text { Muscle } \\
\text { regeneration }\end{array}$ \\
\end{tabular} & $\begin{array}{l}\text { Ex vivo expansion with } \\
\text { regenerative potential }\end{array}$ & $\begin{array}{l}\text { Contribution to } \\
\text { Stem cell poo/ }\end{array}$ & Immunogenicity & $\begin{array}{l}\text { Systemic } \\
\text { delivery }\end{array}$ & References \\
\hline $\begin{array}{l}\text { Bone Marrow- } \\
\text { derived Stem Cells }\end{array}$ & bone marrow & yes & no & yes phenotypic & unknown & yes & [78] \\
\hline iPS cells & skin (fibroblasts) & yes & yes & yes phenotypic & unknown & no & {$[74]$} \\
\hline $\begin{array}{l}\text { Meschenchymal } \\
\text { Stem Cell (MSC) }\end{array}$ & all organs & yes & yes at least 15 passages & no & unknown & yes & [79] \\
\hline $\begin{array}{l}\text { Muscle CD133+ve } \\
\text { cells }\end{array}$ & muscle interstitium/circulation & yes & $\begin{array}{l}\text { limited (blood-derived), } \\
\text { extensive (muscle-derived) }\end{array}$ & yes phenotypic & unknown & yes & {$[80,81]$} \\
\hline Muscle SP cells & muscle interstitium & yes & not tested & $\begin{array}{l}\text { yes functional } \\
\text { (reinjury) }\end{array}$ & low & $\begin{array}{l}\text { not } \\
\text { studied }\end{array}$ & {$[82]$} \\
\hline $\begin{array}{l}\text { Muscle-Derived } \\
\text { Stem Cells }\end{array}$ & unknown & yes & $\begin{array}{l}\text { yes, MDSC were tested at } \\
\text { passage } 10-12\end{array}$ & yes phenotypic & low & no & [83] \\
\hline Myoblasts & myofiber & yes & $\begin{array}{l}\text { easy to culture, loss of } \\
\text { regenerative potential }\end{array}$ & $\begin{array}{l}\text { yes (probably SC } \\
\text { subpopulation) }\end{array}$ & high & no & {$[4]$} \\
\hline $\begin{array}{l}\text { Myoendothelial } \\
\text { cells }\end{array}$ & blood vessels & yes & yes with regenerative potential & no evidence & unknown & no & {$[84]$} \\
\hline $\begin{array}{l}\text { PICs (PW1+ve } \\
\text { cells) }\end{array}$ & muscle interstitium & yes & not tested & yes (phenotypic) & Unknown & $\begin{array}{l}\text { not } \\
\text { studied }\end{array}$ & [71] \\
\hline Satellite Cells & sublaminar & yes & no, loss of regenerative potential & $\begin{array}{l}\text { yes functional (serial } \\
\text { transplantation) }\end{array}$ & low & no & {$[5,7]$} \\
\hline $\begin{array}{l}\text { Vessel-associated } \\
\text { cells }\end{array}$ & blood vessels muscle & yes & early passages were tested & yes phenotypic & low & yes & {$[72,85]$} \\
\hline
\end{tabular}

$1=$ Contribution to muscle regeneration after transplantation is scored

$2=$ Scored positive ('yes') if the studies report regeneration potential in vivo following extensive ex vivo expansion. In most cases freshly isolated cells were evaluated $3=$ Scored positive when functional (e.g. serial transplantations or reinjury experiments) or phenotypic contribution to the stem cell pool was reported. Contribution was scored as 'phenotypic' only if study reports localization to the SC niche with/without expression of Pax7

$4=$ Immunogenicity was considered low, when cells engrafted muscle of immunocompetent hosts

Table 2: Regenerative properties of muscle regenerative cells. The table depicts different types of muscle regenerative cells, most of which are resident to skeletal muscle. Each type of muscle regenerative cell is scored according to the five requirements of the optimal candidate for stem cell therapy (see text).

specific muscles, such as stress urinary incontinence (rhabdosphincter mainly affected) or oculopharyngeal dystrophy (affecting primarily the extraocular muscles)

SCs may also be used to regenerate selected muscles in systemic muscle disorders. For instance, it has been suggested, from a DMD patients' perspective, that it would be invaluable to preserve or improve the function of hand and finger muscles [89]. In addition, the diaphragm muscles in DMD or Pompe's disease would be attractive targets for SC-based therapy.

\section{Muscle stem cells for systemic delivery: vessel-associated cells/Mesangioblasts/Pericytes}

Currently, the most promising candidates for muscle cell-therapy are the cells isolated from the wall of blood vessels in the embryo [90] (mesangioblasts) or in the adult (pericytes) [72]. In adults, mesangioblasts are thought to be a subset of pericytes $[72,85]$. For reasons of clarity, both these cell types are discussed here as vesselassociated cells, which can be isolated from vessels throughout the body, are multipotent, and can differentiate into different types of mesoderm. When isolated from the vessels present in muscle, these cells were shown to be robustly myogenic in vitro and in vivo $[72,90]$. Interestingly, it has been reported that, after transplantation, vesselassociated cells contribute to the SC pool [6]; this was explained by the fact that vessel-associated cells and SCs share a common origin in the embryo. Even in response to muscle-toxins or dystrophy, these 'vesselassociated cell-derived' satellite cells expressed Pax7, and contributed to muscle homeostasis and regeneration [6]. This may explain their ability to contribute to muscle regeneration under certain conditions, for example after transplantation to distressed muscle.

Their muscle-regenerative (and therapeutic) potential is clearly indicated by their ability to restore or ameliorate the dystrophic phenotype after transplantation to dystrophic mice ( $\alpha$-sarcoglycannull mice [91] and dysferlin-deficient mice [92]) and golden retriever muscular dystrophy (GRMD) dogs [85]. The ability of vessel-associated cells to morphologically and functionally restore the dystrophic phenotype in $\alpha$-sarcoglycan-null mice (the animal model for limbgirdle muscular dystrophy 2D) indicated that a robust immune response to these cells was lacking or did not limit engraftment. In line with this, vessel-associated cells from sources other than muscle are shown to have low immunogenicity $[93,94]$. Given the robust immune response (and hence limited engraftment) observed after myoblast transplantation, this property may be an important attribute for the therapeutic potential of vessel-associated cells

One drawback may be, that in the absence of well-defined markers, that it has been found to be difficult to prepare pure populations of vessel-associated cells with robust reproducible regenerative potential [95]. Additional cell types may contaminate the isolates and fail to contribute to regeneration, thereby affecting the experimental outcome.

Vessel-associated cells are attractive candidate for therapy due not only to their muscle-regenerative potential, but also to their ability to proliferate in vitro. It was reported that they could be expanded by up to 20 population-doublings before undergoing senescence. This was claimed to be sufficient to treat a young patient [72].

In conclusion, the properties of vessel-associated cells, particularly their compatibility with systemic delivery, makes these cells good candidates for treating systemic muscle disorders such as DMD and limb-girdle muscular dystrophy.

\section{The Ex-vivo Expansion of Regenerative Cells}

SCs comprise about $\sim 4 \%$ of myonuclei in human adult muscle, and only limited numbers of regenerative cells can be obtained from patient muscle samples. This indicates that extensive ex-vivo expansion 
is required to increase cell numbers - and thereby the feasibility of cell-therapy. However, culturing freshly isolated (mouse) SCs and human muscle progenitors leads to the generation of committed progenitors whose regenerative potential is reduced [83,96-98]. This loss of regenerative potential upon ex-vivo expansion is not unique to the culturing of SCs: it is also acknowledged for other types of stem cell that are used for therapy, including hematopoietic stem cells [99]. Even vessel-associated cells, which can be expanded rather extensively ex vivo, eventually undergo senescence, while further expansion may be required to treat adult or severely affected patients.

The need for refined culturing techniques is most apparent for SCs, and great progress has been made in understanding the mechanisms that regulate their stem-cell properties. Here we discuss various culturing techniques described in several studies, and how they may be used in future studies to expand cells with the highest regenerative potential.

\section{Understanding the regulation of stem-cell fate}

The endogenous stem-cell pool is maintained in vivo through the tight regulation of self-renewal and differentiation. The regulation of these processes is highly complex and is determined largely by environmental factors. The importance of the stem-cell microenvironment, or niche, has been convincingly shown for SCs. SCs are polarized cells with a basal membrane rich in $\alpha 7 / \beta 1$-integrin that is in direct contact with the laminin-rich basal lamina surrounding the myofibers. The apical membrane of the SC expresses M-cadherin and receives signals from the myofiber. Displacement of one SC daughter cell from the niche after dividing perpendicular to the length axis of the myofiber results in lineage commitment of the apical daughter. The basal daughter remains in the niche (defined by the basal lamina) and retains the stem-cell fate. In contrast, SCs dividing in a planar orientation generate daughter cells with identical stem-cell fates, as the dividing cells maintain contact with the basal lamina [100].

Other indications for the dominant effect of the environment on stem-cell fate were obtained from heterochronic transplantation studies. Satellite cells' age-related loss of regenerative potential could be restored by heterochronic transplantation of aged SCs into a young environment, while the reverse transplantations were ineffective $[57,59]$. The importance of the proper environment in dictating the regenerative potential of its associated stem cells is further demonstrated by the success of intact single-myofiber transplantation in contributing to new myofibers and the generation of donor-derived SCs $[55,101]$. During the transplantation procedure the SCs remained in their natural niche in these intact myofibers, which is thought to be vital for ensuring their robust regenerative potential. The results of these studies strongly suggest that the signals for governing cell fate and regenerative potential can be identified by dissecting the SC microenvironment. The niche is composed of both soluble and solid biochemical signals (oxygen, growth factors, nutrients, cytokines, extracellular matrix proteins), and confers biophysical signals (e.g. matrix stiffness, fluidity, oxygen tension).

In addition to signals from the environment, cell-specific factors are critical, and the cell within the niche should be properly programmed to interpret the stem-cell signals. This has been shown for bone-marrowderived cells (BMDC), which occasionally occupy the SC niche [102]. These BMDCs did not acquire a myogenic fate during their residency in the SC niche.

Furthermore, there are numerous examples where conditional targeting (e.g. inactivation) of a SC-specific gene that had no affect on the niche, resulted in activation, proliferation and often premature differentiation of SCs. For instance, a recent study targeted Myf5 mRNA expression by inactivating Mir31, which targets Myf5 in quiescent stem cells and prevents accumulation of Myf5 protein [103]. Myf5 belongs to the family of muscle regulatory factors (MRFs), which also includes MyoD, MRF4 and myogenin, and is expressed in quiescent satellite cells and early muscle progenitors. After inactivating Mir31 by the intramuscular injection of specific antagomirs (chemically designed oligonucleotides used to silence Mirs), quiescent satellite cells re-entered the cell-cycle, and muscle regeneration increased; this was deduced by the presence of an increased number of small embryonic myosin heavy chain (eMHC; detected only in regenerating myofibers) positive myofibers. In addition, two recent studies showed that conditional SC-specific inactivation of RBP-J, a nuclear factor essential in Notch signaling, resulted in SC depletion and loss of muscle-regenerative potential $[104,105]$, while the niche remained intact in these animals. These studies indicate that targeting of certain cell-intrinsic factors dictates cell fate, an effect that may be exploited during ex-vivo culturing.

\section{Expanding or selecting subpopulations with higher regenerative potential}

SC populations are phenotypically and functionally heterogeneous [106], their regenerative potential varying between SC subpopulations. The heterogeneity in regenerative potential of SC subpopulations is maintained ex vivo $[75,87,107,108]$, which may allow the selection and expansion of the most highly regenerating subpopulations. All one would need is to identify and trigger the proper stimuli.

A recent study took a label-retention approach to selecting the slow-dividing cell population from SC-derived muscle cultures [107]. In several types of tissues and cultures there are indications that slowly dividing cells represent the subpopulation with increased stemcell potential. For instance, quiescent HSC demonstrated increased survival after transplantation, while short-term culture induced cellcycle reentry and failure to reconstitute NOD/SCID animals $[109,110]$. In line with this, the slowly dividing population identified in murine SC-derived muscle cultures was shown to harbor increased myogenic potential in vivo and to generate a functional SC population [107]. The dyes used for label-retaining experiments are DNA-binding chemicals, so to use this strategy for clinical purposes the safety of label will be a relevant issue.

On the basis of the hypothesis that the ALDH ${ }^{\text {hi }}$ population would harbor increased resistance to oxidative stress, another study selected a subpopulation of cells expressing high levels of alcohol dehydrogenase $\left(\mathrm{ALDH}^{\mathrm{hi}}\right)$ from murine and human muscle cultures. Oxidative stress is thought to be one of the major factors that limited myoblast engraftment in the early myoblast transfer studies [111]. The study by Vella and co-authors indicated that stress resistance, proliferation, differentiation and muscle regeneration were increased in the $\mathrm{ALDH}^{\mathrm{hi}}$ population of both species.

FACS sorting is widely used to enrich for cell populations, $[112,113]$, and several cell-surface markers, including CXCR4 and CD133, have been reported to allow the isolation of highly regenerative cells directly from donor muscle $[5,7,80]$. These sorted subpopulations have a high regenerative potential, and it would be of clinical interest to expand them ex vivo. As transplantation studies have shown that only a limited number of such cells would be needed to obtain 
robust engraftment potential [7], a minimal ex-vivo expansion may be required. Unfortunately, these FACS-sorted populations either lose their regenerative potential upon ex-vivo expansion [7], or have limited potential to proliferate in vitro [80]. So, to maintain the high level of regeneration potential, FACS-sorted populations should be cultured under optimized conditions, as will be described below (e.g. by stimulating self-renewing expansion).

Alternatively, as muscle populations remain heterogeneous in culture and harbor subpopulations with increased regenerative potential [87], a FACS-sorting strategy may allow purification of engraftment-competent cells from extensively expanded muscle cultures. So far, however, no cell surface marker (s) have been identified that could be used for such a strategy, although this is currently one of the main interests in our laboratory.

\section{Inducing self-renewing expansion}

Much work has been done to understand the molecules that contribute to the self-renewal of SCs and prevent their premature differentiation. These studies have revealed important roles for soluble signaling molecules, including Notch and Wnt ligands, and also for several membrane proteins such as caveolin-1 and syndecan $3 / 4$ (reviewed by Kuang et al. [114]). Most of the knowledge is derived from studies investigating this mechanism in vivo, but the importance of these pathways for self-renewal have been verified in vitro [98].

The importance of the Notch pathway in regulating SC behavior and size of the SC pool was shown in earlier studies where pharmacological inhibition of Notch signaling inhibited the proliferation and selfrenewal potential of SCs, while the enhancement of Notch activity restored the regeneration potential of aged muscle $[58,100]$. As stated above, SC-specific inhibition of Notch signaling in vivo by conditional inactivation of RBP/J induced premature differentiation. These Notchinhibited SCs differentiated without first undergoing cell division and fused with adjacent fibers. As a result, the SC pool was gradually depleted $[104,105]$. A similar effect was shown on embryonic muscle progenitors after deleting RBP/J [115]. In Hes 1/3 double knockout mice (downstream target genes of Notch signaling), a defect in generating undifferentiated SC was observed and SC numbers decreased gradually [116]. On the other hand, constitutive Notch activation in vivo increased Pax7 expression and promoted SC self-renewal [86].

Notch activity was shown to also determine self-renewal and increase the number of undifferentiated SCs (Pax7+/MyoD-) in vitro [100]. To investigate this, a recent study evaluated the role of Notch signaling on SC self-renewal by culturing canine satellite-cell-derived myoblasts on polystyrene culture plates coated with IgG-bound Notch ligand Delta $1^{\text {ext }}[98]$. Upon transplantation, the myoblasts that had been expanded on Notch ligand contributed to muscle regeneration as efficiently as freshly isolated myoblasts. Furthermore, the Delta1 ${ }^{\text {ext }}$ expanded cells generated stem cells in vivo - in other words, they were capable of self-renewal. This was shown by the engraftment of the Delta $1^{\text {ext }}$-expanded cells in secondary recipients [98]. These experimental outcomes show that Notch signaling is important to SC self-renewal, and that manipulation of Notch should be considered for ex-vivo expansion protocols.

In addition to Notch signaling, the Wnt pathway is known to contribute to SC self-renewal and cell-fate choice in vivo [117-119]. Wnt7a, but not Wnt3a, was shown to activate planar cell division (see above), thereby promoting symmetric satellite-cell expansion in vivo [118]. It can be assumed that activation of the Wnt pathway helps to induce the self-renewing expansion of cultured SCs. Indeed, Wnt7a was shown to promote self-renewing division of Pax $7+/ \mathrm{MyoD}$ - SCs, but only in isolated myofiber cultures and not in primary myoblasts grown on a regular culture dish [118]. Le Grand and colleagues determined that stimulation of self-renewing division by Wnt7a proceeded through the Wnt planar polarity pathway (PCP) [118]. This indicated that maintenance of cell polarity is essential to mediating the effect of Wnt7a. In myofiber cultures, SCs are in their natural environment and cell polarity is maintained [100], while in regular 2D cultures polarity is lost. Although the study of Le Grand and colleagues showed that Wnt activity regulated symmetric self-renewing expansion of SCs, pharmacological stimulation of Wnt activity may not be sufficient. Instead it may be necessary to reconstruct the niche in vitro. For instance, to maximize benefit from soluble factors (such as Wnt7a) that promote self-renewing divisions of cultured SCs, it may be necessary to optimize the culture substrate (discussed below).

\section{Expanding SCs under hypoxic conditions}

Tissue stem-cell niches, including those housing SCs [120], tend to be hypoxic, a condition that may be important for the function and survival of stem cells. In line with this, quiescent SC survived and retained regenerative activity in postmortem muscle tissue and severe hypoxia was found to be essential for the maintenance of these highly regenerative cells [121].

Based on these and other observations, it has been suggested that culturing stem cells in hypoxic conditions may more closely approach the in-vivo situation and promote their stem-cell function. This was initially shown for neural crest [122] and CNS [123] stem cells. Hypoxia was also found to increase the efficiency of generating iPS cells [124]. In addition, the differentiation of mouse myogenic cells grown under hypoxia was inhibited $[125,126]$, presumably through increased degradation of MyoD [125]. The effect of hypoxia, which was shown to depend on Notch activity, activated Notch downstream genes through binding of the Notch intracellular domain with HIF1a [126]. In line with this finding and the effect of Notch activity on the self-renewing expansion of cultured myogenic cells [98], hypoxia was found to increase the self-renewing cell divisions of mouse SCs and to enhance their engraftment potential [127]. Interestingly, hypoxia was also shown to induce myogenic proliferation of human muscle progenitors [128], but as the effect on engraftment potential has not yet been determined, it remains to be determined whether the cells underwent self-renewal divisions.

An in-vivo tissue chamber model has been used to demonstrate that engraftment efficiency is increased by exposing (rat) muscle cells to hypoxic conditions before transplantation, a procedure called preconditioning (see below) [129]. The beneficial effect is thought to reside in the cells' adjustment to the hypoxic environment of the host muscle. Taken together, the increased regenerative potential of cells expanded in hypoxic conditions may be multifactorial, but offers a minimally invasive approach to improving the regenerative potential of stem-cell cultures.

\section{Maintaining stem cells in suspension/spheroid culture}

When cultured under low adhesion conditions, cells isolated from different tissues, including the breast [130], heart [131] and endothelium [132], spontaneously aggregate and form spheres. While differentiated cells stop dividing under these conditions, stem cells continue to proliferate [133], providing a relatively simple approach to enrich for tissue-specific stem cells. The effect of sphere-culture may be 
explained by their different cellular organization, which is closer to that in vivo, but also by altered biophysical signals resulting from a change in cell morphology and loss of contact with the substrate. Irrespective of the mechanism, the stem-cell properties of both mouse and human muscle stem cells appear to be preserved in spheroid culture and to result in enrichment of engraftable cells during expansion under these conditions [134-136]. Interestingly, human muscle cells could be expanded for at least 5 months under spheroid conditions and could undergo 40 population doublings before going into senescence [135]. While this strategy may yield sufficient number of cells for treatment, it should be noted that the study using human muscle cells did not determine the engraftment efficiency of the myosphere cultures [135].

\section{Inducing SC activation and proliferation: a two-step approach}

After activation, in-vivo quiescent SCs enter the cell cycle and proliferate [137]. Most of the population progresses to committed myoblasts, which continue to divide for limited a number of cycles before differentiating into myocytes. The activation of SCs is dependent on several factors including sphingolipid signaling [138], NO production (which results in vivo in release of HGF from the ECM) [139]; and growth factors (bFGF, IGF, IL-6). Several studies indicate that these signals also promote SC proliferation in vitro and may be used to rapidly expand the isolated muscle cells. As discussed above, expanding SC-derived cultures under proliferation conditions dramatically reduces their regenerative potential [7]. However, this strategy may currently be the only option for expanding human muscle progenitors. Unlike murine cultures, human muscle progenitor cells do not proliferate extensively in vitro, and undergo a limited number of divisions before entering senescence [140]. Unfortunately, not much is known on the specific factors that promote the proliferative capacity of human cells. Some pathways, including IGF-signaling [141] and the TGF-beta pathway [142] (myostatin, a member of the TGFbeta superfamily, negatively affects muscle progenitor proliferation), control the proliferative activity of human muscle progenitors. The maintenance of the proliferative potential of human muscle progenitors is important not only for their eventual clinical applications, but even more to facilitate the study of the behavior of these cells in culture.

Once the conditions for efficiently expanding human muscle progenitors have been established, strategies should be followed to restore or increase the regenerative potential just prior to transplantation. This suggests that a two-step approach should be developed to obtain human muscle-regenerative cells as depicted in Figure 2 (indicated by the red arrows). Several approaches have been described that can be used to achieve this, including preconditioning, exposing the cells to hypoxia, or limiting oxidative stress in the transplanted population.

The first of these approaches, preconditioning, is defined as the exposure to a sublethal insult prior to transplantation in order to induce a protective response before transplantation that will allow the cells to better survive the hostile environment of the host tissue. Preconditioning has been studied mainly in the context of whole-organ transplantations, but recent studies suggest that cell-therapy strategies may also benefit from this procedure. In a tissue-engineering chamber model, preconditioning of myoblasts with the nitric oxide (NO) donor DETA-NONOate increased survival (and proliferation) after implantation [129].

With regard to hypoxia, we have stated above that preconditioning cells under hypoxic conditions to mimic the oxygen pressure in the host tissue was shown to enhance the transplantation efficiency of satellite cell-derived myoblasts [127]. The beneficial effect of hypoxia was reported to increase engraftment almost 2 -fold, but needs to be refined.

The third approach, increasing resistance to oxidative stress, may boost the engraftment potential of the cells expanded ex vivo. The damaged or dystrophic host muscle may prove to be a rather hostile environment for transplanted cells, being characterized by necrotic and apoptotic tissue, infiltration of inflammatory cells, and deposits of nonmyogenic material. The identification of signals that adversely affect engraftment are as relevant as signals promoting engraftment. The transplanted cells may initially undergo increased levels of oxidative stress, which is thought to reduce the success of engraftment [111]. It has been suggested that engraftment may be positively affected by adapting the conditions to limit the levels of oxidative stress in culture. Cells can be exposed to anti-oxidants, such as $\mathrm{N}$-acetyl cysteine or sodium ascorbate [111,143], during ex-vivo expansion or just before transplantation. Relative to engraftment potential of untreated cells, the transplantation of antioxidant-treated cells increased the formation of donor-host fibers about 1.7 fold [111].

\section{Effect of stiffness of the culture substrate}

The importance of defining the appropriate biophysical properties on the myogenic and regenerative potential of muscle cells has been shown in studies using various types of culture substrates to modify elastic stiffness. C2C12 myoblasts cultured on collagen-coated polyacrylamide gels, which approached the elasticity of skeletal muscle $(\sim 12 \mathrm{KPa})$, differentiated more efficiently than cells maintained on 'hard' plastic [144]. In addition, a direct correlation has been observed between the stiffness and proliferation rates (higher stiffness leads to increased proliferation [144]).

More recently, freshly isolated SCs cultured on polyethylene glycol (PEG)-based hydrogels with the same rigidity of muscle in vivo $(\sim 12 \mathrm{KPa})$ self-renewed in vitro, and contributed more efficiently to muscle regeneration in vivo than SCs cultured on regular plastic substrates. In both studies, the use of both softer and harder substrates resulted in decreased performance in the in-vitro and in-vivo assays used, indicating there is an optimal culture substrate formulation. As suggested, it will be interesting to determine whether the number of regenerative cells may be further increased by combining elastic substrates with chemically-defined media.

\section{Generation of muscle progenitor cells by reprogramming somatic cells}

In recent years it has become possible to use transient expression of 3-4 transcription factors to reprogram somatic cells to induced pluripotent stem (iPS) cells $[145,146]$. Phenotypically and functionally, iPS cells resemble embryonic stem (ES) cells, and can be expanded in vitro for many passages while maintaining both pluripotency and the ability to differentiate into cells of all three germ layers [146]. This also eliminates the ethical considerations associated with ES cells. On the basis of these properties, iPS cells can be proposed as an attractive alternative to somatic cells.

The clinical application of iPS technology faces two major challenges: 1) how these cells can be derived without altering the genome, and 2) how they can be differentiated to homogeneity of the desired cell type. Common methods of generating iPS cells use retroviral or lentiviral gene delivery with the risk of insertional mutagenesis. 


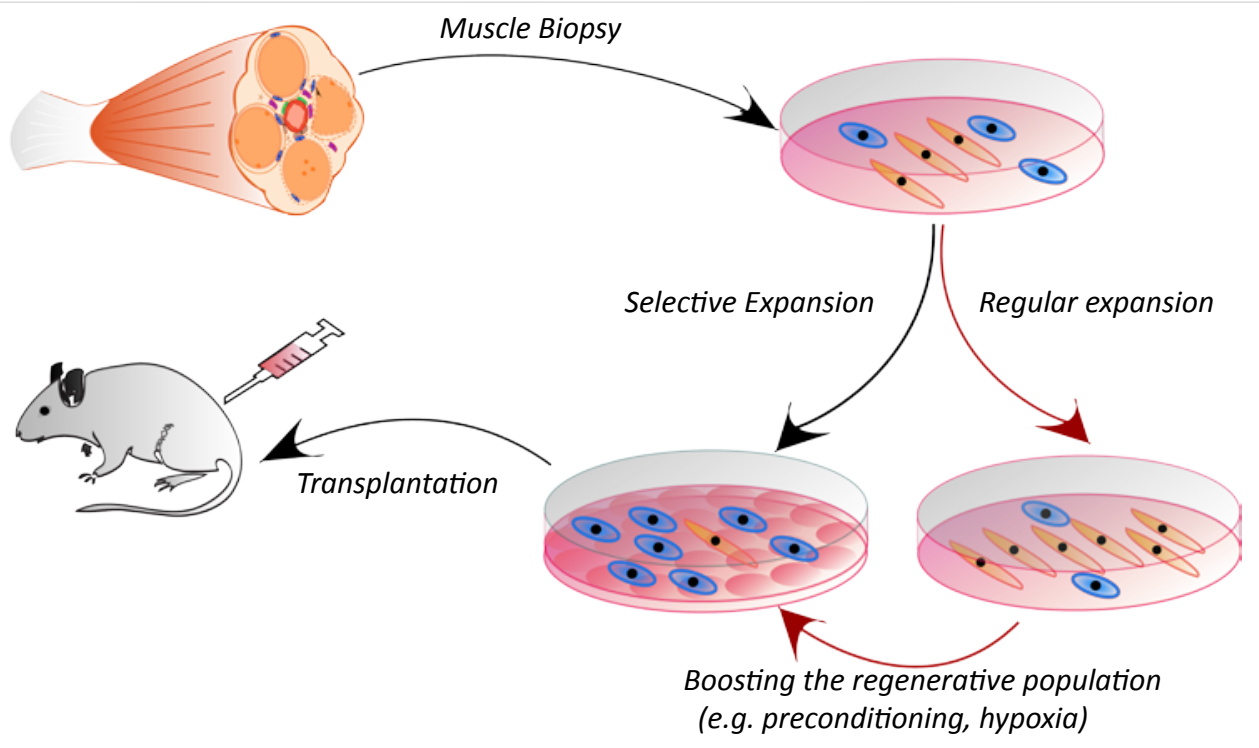

Satellite cell (engrafting cell)

Muscle progenitor/ Myoblast (non-engrafting cell)

Defined culture substrate (e.g. PEG based hydrogel or Delta Notch ligand)

Figure 2: Selective expansion of muscle regenerative cells. The figure depicts two different strategies to obtain cultures enriched with muscle regenerative cells: a 'two-step' approach and the selective expansion of highly regenerative cells. These procedures start with the establishment of a muscle culture from a small biopsy. The culture is heterogeneous and contains a subpopulation of cells capable of engraftment.

Two-step approach: The cultures may be cultured under 'regular' conditions in order to expand the cells rapidly and extensively. Subsequently, strategies, such as preconditioning or exposing the cultures to hypoxic conditions (see text for details), can be applied to boost the regenerative potential of the expanded cells prior to transplantation (referred to as a two-step approach in the text; red arrows). The efficiency of this strategy may be low, because of the extensive loss of regenerative potential in the first step and the modest restoration ( 2-fold) of the regenerative potential in the second step of the protocol.

Selective expansion: Alternatively, the mechanisms of stem cell self-renewal in vivo may are applied to cultured cells (e.g. use of PEG-based hydrogel-based culture substrates or use of immobilized Notch ligand; see text). We hypothesize that such well-defined culture conditions promote the selective (self-renewing) expansion and, consequently, enrichment of engraftment-competent cells. It is expected that limited numbers of cells from such enriched cultures are required for efficient engraftment and regeneration.

Proper differentiation is important not only to obtaining the cell type of choice, but also to eliminating remaining pluripotent cells, which can form teratomas when placed in the wrong (non-embryonic) environment. Recently, important progress has been made. Various methods for non-viral gene expression have been reported, including those using Cre recombinase-mediated transgene excision [147] and gene expression via the non-integrating Sendai virus [148].

A number of reports document the successful generation of myogenic progenitors from mouse and human iPS cells, and engraftment of these cells in mouse models for human muscular dystrophies [149-154]. Major differences between various studies include the protocol used for generating myogenic progenitors, the efficiencies of these efforts, and the capacities of the cells generated for showing long-term engraftment and functional improvement.

An efficient method that results in successful long-term engraftment and functional improvement (i.e. 8 months in the mouse) was reported recently by Darabi et al. who, based on previous observations using mouse embryonic stem (ES) or iPS cells $[155,156]$, used inducible expression of pax7 during embroid body formation of human iPS cells. A straightforward FACS sorting approach based on co-expressed GFP proved sufficient to purify myogenic progenitors to homogeneity; no teratomas were observed after transplantation. The endogenous markers used for purification in the mouse were PDGF+/
Flk- $[155,156]$, though it is unclear whether these markers may be used in human as well. Importantly, intramuscular injection into the Tibialis Anterior muscle of a mouse model for Duchenne Muscular Dystrophy resulted in successful engraftment and the partial restoration of dystrophin expression. Donor dystrophin expression was still present 46 weeks after transplantation. Similarly, muscle function improved and a fraction of engrafted cells contributed to the endogenous SC population, suggesting that the iPS-derived progenitors self-renewed in vivo.

This work thus presents an important proof of principle for using iPS cells in the long-term treatment of muscular dystrophy. Challenges for the future include efficient 1) generation of human iPS cells, 2) gene correction 3) cell differentiation without functionally changing the human genome and 4) the efficient delivery of cells to various muscles using intravenous or intra-arterial administration.

\section{Conclusion}

Despite its promise and potential, cell-based therapy for muscular dystrophies is still in its infancy. Although the clinical efficacy of myoblasts has turned out to be rather disappointing, the identification of additional cell types or populations - especially satellite cells and vessel-associated cells that can regenerate muscle - provide new hope for cell-oriented therapy. Their specific properties would indicate use in 
the treatment of distinct muscle diseases, which require either systemic (vessel associated cells) or local delivery (SCs). The progress in the field of cell-based therapy for skeletal muscle is underscored by the stage I clinical trials with vessel-associated cells for the treatment of DMD that started in 2011, whose results are awaited impatiently. SCs have not advanced to this stage as of yet and several issues require attention.

Most of the work on SCs has been performed with murine cells, and it must still be determined whether the findings described above can be applied to human SCs. Although it has been established that mouse and human SCs share many properties (reviewed in [157]) - including the ability to regenerate muscle upon transplantation - there are some striking differences. The isolation of human SCs is complicated by the lack of highly specific markers, and, despite some strong initial indications these cells, too, are bona fide stem cells, it remains uncertain whether they self-renew in vivo [158].

The progress with human muscle progenitors is dependent on methods to overcome their limited proliferative potential in culture. In the short term, the 'two-step' approach discussed above (Figure 2) may be the most feasible strategy for human muscle progenitors, but strategies such as preconditioning and oxidative stress increase regenerative potential only modestly. The expansion of self-renewing cells seen in murine cultures would greatly increase the regenerative potential of the cultures that will be used for transplantation. In this respect, the identification of the reserve cell (RC) in human muscle progenitor cultures [159] is very promising. Like their counterparts in mice $[87,160]$, human muscle progenitor cultures have been shown to harbor a population of reserve cells (RC). Reserve cells are mononuclear cells that, under differentiation conditions, escape from differentiation and are thought to have properties of muscle stem cells $[159,160]$. It would be of major future interest and clinical importance to identify the mechanisms or factors that contribute to their specific maintenance or expansion ex vivo.

The next major milestone that can be envisioned for human muscle progenitors would be the evaluation of their therapeutic potential in a relevant (pre-) clinical setting that involves the isolation of human SCs, their expansion and finally transplantation to a suitable animal model. Only under these conditions the putative therapeutic potential of expanded human SC-like muscle progenitors can be evaluated. The importance of the immune system and its avoidance to engraftment success dictates that an animal model should be used that develops a relevant (i.e. human) immune response against the transplanted cells. The animal model should also make it possible to quantify the change in muscle function after cell transplantation. Given these requirements, it will be valuable to develop a humanized mouse model [161] with a muscle phenotype. Such a model will also be valuable to the various laboratories that aim to use human muscle-regenerative cells for therapy.

A general issue of importance associated with cell-therapy is safety. The transplantation of $\mathrm{C} 2 \mathrm{C} 12$ myoblasts, a myoblast cell line established in the late 1970s by Yaffe and Saxel [162] was associated with muscle regeneration, but also with a propensity for generating tumors under certain conditions in vivo. It is thought that the cells may acquire a certain level of genomic instability and subsequent tumorigenic activity during the extended in-vitro expansion. Indeed, it has recently been shown that MDSCs acquired a transformational phenotype when expanded over 200 population doublings ex vivo [163]. This further underscores the importance of defining optimized conditions for expanding cells with the highest regenerative potential that may already achieve a functional effect at reduced numbers and require minimal expansion ex vivo.

A major advantage of including an ex-vivo expansion phase is that quality-control parameters can be implemented and Good Manufacturing Practice (GMP) guidelines be applied (see (http:// www.emea.europa.eu/), enabling the generation of highly reproducible cell-products. More than any other technology, iPS offers the potential to generate large batches of well-defined regenerative cells that can be stored until use.

In conclusion, muscle regenerative cells remain attractive novel tools for the treatment of muscle disorders and much progress in understanding the behavior of these cells in vitro and in vivo has been made. However, it is also clear that several challenges, both with respect to practical issues and regulations, remain before introduction of a cellbased therapy for the treatment of muscle disorders becomes reality.

\section{Acknowledgement}

This work was partly possible through the support of NWO (Netherlands Organization for Scientific Research; Veni Grant 91656165). The authors wish to thank Dr. L. van den Berg for discussion and ideas with regard to this review and David Alexander for his critical reading of the manuscript.

\section{References}

1. Gatti RA, Meuwissen HJ, Allen HD, Hong R, Good RA (1968) Immunological reconstitution of sex-linked lymphopenic immunological deficiency. Lancet 2 1366-1369.

2. Huard J, Labrecque C, Dansereau G, Robitaille L, Tremblay JP (1991) Dystrophin expression in myotubes formed by the fusion of normal and dystrophic myoblasts. Muscle Nerve. 14: 178-182.

3. Karpati G, Pouliot Y, Zubrzycka-Gaarn E, Carpenter S, Ray PN, et al. (1989) Dystrophin is expressed in $\mathrm{mdx}$ skeletal muscle fibers after normal myoblas implantation. Am J Pathol 135: 27-32.

4. Partridge TA, Morgan JE, Coulton GR, Hoffman EP, Kunkel LM (1989) Conversion of $\mathrm{mdx}$ myofibres from dystrophin-negative to -positive by injection of normal myoblasts. Nature 337: 176-179.

5. Cerletti M, Jurga S, Witczak CA, Hirshman MF, Shadrach JL, et al. (2008) Highly efficient, functional engraftment of skeletal muscle stem cells in dystrophic muscles. Cell 134: 37-47.

6. Dellavalle A, Maroli G, Covarello D, Azzoni E, Innocenzi A, et al. (2011) Pericytes resident in postnatal skeletal muscle differentiate into muscle fibres and generate satellite cells. Nat Commun 2: 499.

7. Sacco A, Doyonnas R, Kraft P, Vitorovic S, Blau HM (2008) Self-renewal and expansion of single transplanted muscle stem cells. Nature 456: 502-506.

8. Meng J, Muntoni F, Morgan JE (2011) Stem cells to treat muscular dystrophies - where are we?. Neuromuscul Disord 21: 4-12.

9. Péault B, Rudnicki M, Torrente Y, Cossu G, Tremblay JP, et al. (2007) Stem and progenitor cells in skeletal muscle development, maintenance, and therapy. Mol Ther 15: 867-877.

10. Price FD, Kuroda K, Rudnicki MA (2007) Stem cell based therapies to treat muscular dystrophy. Biochim Biophys Acta 1772: 272-283.

11. Vilquin JT, Catelain C, Vauchez K (2011) Cell therapy for muscular dystrophies: advances and challenges. Curr Opin Organ Transplant 16: 640-649.

12. Brack AS, Rando TA (2012) Tissue-specific stem cells: lessons from the skeletal muscle satellite cell. Cell Stem Cell 10: 504-514.

13. van der Ploeg AT, Reuser AJ (2008) Pompe's disease. Lancet 372: 1342-1353.

14. Manzur AY, Muntoni $F$ (2009) Diagnosis and new treatments in muscular dystrophies. J Neurol Neurosurg Psychiatry 80: 706-714

15. Bushby K (2009) Diagnosis and management of the limb girdle muscular dystrophies. Pract Neurol 9: 314-23.

16. Sicinski P, Geng Y, Ryder-Cook AS, Barnard EA, Darlison MG, et al. (1989) The molecular basis of muscular dystrophy in the mdx mouse: a point mutation. 
Citation: Schaaf G, Sage F, Stok M, Brusse E, Pijnappel WWM, et al. (2012) Ex-vivo Expansion of Muscle-Regenerative Cells for the Treatment of Muscle Disorders. J Stem Cell Res Ther S11:003. doi:10.4172/2157-7633.S11-003

Science 244: 1578-1580

17. Miyagoe Y, Hanaoka K, Nonaka I, Hayasaka M, Nabeshima Y, et al. (1997) Laminin alpha2 chain-null mutant mice by targeted disruption of the Lama2 gene: a new model of merosin (laminin 2)-deficient congenital muscular dystrophy. FEBS Lett 415: 33-39.

18. Mayer U, Saher G, Fässler R, Bornemann A, Echtermeyer F, et al. (1997) Absence of integrin alpha 7 causes a novel form of muscular dystrophy. Nat Genet 17: 318-323.

19. Takeda S, Kondo M, Sasaki J, Kurahashi H, Kano H, et al. (2003) Fukutin is required for maintenance of muscle integrity, cortical histiogenesis and normal eye development. Hum Mol Genet 12: 1449-1459.

20. Rederstorff M, Castets $P$, Arbogast S, Lainé J, Vassilopoulos S, et al. (2011) Increased muscle stress-sensitivity induced by selenoprotein $\mathrm{N}$ inactivation in mouse: a mammalian model for SEPN1-related myopathy. PLoS One 6: e23094.

21. Sharp NJ, Kornegay JN, Van Camp SD, Herbstreith MH, Secore SL, et al (1992) An error in dystrophin mRNA processing in golden retriever muscular dystrophy, an animal homologue of Duchenne muscular dystrophy. Genomics 13: $115-121$

22. Ozawa R, Hayashi YK, Ogawa M, Kurokawa R, Matsumoto $\mathrm{H}$, et al. (2006) Emerin-lacking mice show minimal motor and cardiac dysfunctions with nuclear-associated vacuoles. Am J Pathol 168: 907-917.

23. Sullivan T, Escalante-Alcalde D, Bhatt H, Anver M, Bhat N, et al. (1999) Loss of A-type lamin expression compromises nuclear envelope integrity leading to muscular dystrophy. J Cell Biol 147: 913-920.

24. Gabellini D, D’Antona G, Moggio M, Prelle A, Zecca C, et al. (2006) Facioscapulohumeral muscular dystrophy in mice overexpressing FRG1. Nature 439: 973-977.

25. Bittner RE, Anderson LV, Burkhardt E, Bashir R, Vafiadaki E, et al. (1999) Dysferlin deletion in SJL mice (SJL-Dysf) defines a natural model for limb girdle muscular dystrophy 2B. Nat Genet 23: 141-142.

26. Nigro V, Okazaki Y, Belsito A, Piluso G, Matsuda Y, et al. (1997) Identification of the Syrian hamster cardiomyopathy gene. Hum Mol Genet 6: 601-607.

27. Willer T, Prados B, Falcón-Pérez JM, Renner-Müller I, Przemeck GK, et al (2004) Targeted disruption of the Walker-Warburg syndrome gene Pomt1 in mouse results in embryonic lethality. Proc Natl Acad Sci USA 101: 1412614131.

28. Berul Cl, Maguire CT, Aronovitz MJ, Greenwood J, Miller C, et al. (1999) DMPK dosage alterations result in atrioventricular conduction abnormalities in a mouse myotonic dystrophy model. J Clin Invest 103: R1-R7.

29. Chen W, Wang Y, Abe Y, Cheney L, Udd B, et al. (2007) Haploinsuffciency for Znf9 in Znf9+/- mice is associated with multiorgan abnormalities resembling myotonic dystrophy. J Mol Biol 368: 8-17.

30. Hino H, Araki K, Uyama E, Takeya M, Araki M, et al. (2004) Myopathy phenotype in transgenic mice expressing mutated PABPN1 as a model of oculopharyngeal muscular dystrophy. Hum Mol Genet 13: 181-190.

31. Bijvoet AG, van de Kamp EH, Kroos MA, Ding JH, Yang BZ, et al. (1998) Generalized glycogen storage and cardiomegaly in a knockout mouse model of Pompe disease. Hum Mol Genet 7: 53-62.

32. Raben N, Lu N, Nagaraju K, Rivera Y, Lee A, et al. (2001) Conditional tissuespecific expression of the acid alpha-glucosidase (GAA) gene in the GAA knockout mice: implications for therapy. Hum Mol Genet 10: 2039-2047.

33. Hijaz A, Daneshgari F, Sievert KD, Damaser MS (2008) Animal models of female stress urinary incontinence. J Urol 179: 2103-2110.

34. Suga T, Kurabayashi M, Sando Y, Ohyama Y, Maeno T, et al. (2000) Disruption of the klotho gene causes pulmonary emphysema in mice. Defect in maintenance of pulmonary integrity during postnatal life. Am J Respir Cell Mol Biol 22: 26-33.

35. Heslop L, Morgan JE, Partridge TA (2000) Evidence for a myogenic stem cell that is exhausted in dystrophic muscle. J Cell Sci 113: 2299-2308.

36. Rooney JE, Welser JV, Dechert MA, Flintoff-Dye NL, Kaufman SJ, et al. (2006) Severe muscular dystrophy in mice that lack dystrophin and alpha7 integrin. $J$ Cell Sci 119: 2185-2195
37. Castets P, Bertrand AT, Beuvin M, Ferry A, Le Grand F, et al. (2011) Satellite cell loss and impaired muscle regeneration in selenoprotein $\mathrm{N}$ deficiency. Hum Mol Genet 20: 694-704.

38. Frock RL, Kudlow BA, Evans AM, Jameson SA, Hauschka SD, et al. (2006) Lamin A/C and emerin are critical for skeletal muscle satellite cell differentiation. Genes Dev 20: 486-500.

39. Geng LN, Yao Z, Snider L, Fong AP, Cech JN, et al. (2012) DUX4 activates germline genes, retroelements, and immune mediators: implications for facioscapulohumeral dystrophy. Dev Cell 22: 38-51.

40. Wallace LM, Garwick SE, Mei W, Belayew A, Coppee F, et al. (2011) DUX4 a candidate gene for facioscapulohumeral muscular dystrophy, causes p53dependent myopathy in vivo. Ann Neurol 69: 540-552.

41. Doherty KR, Cave A, Davis DB, Delmonte AJ, Posey A, et al. (2005) Normal myoblast fusion requires myoferlin. Development 132: 5565-5575.

42. Ueyama M, Akimoto $\mathrm{Y}$, Ichimiya T, Ueda R, Kawakami H, et al. (2010) Increased apoptosis of myoblasts in Drosophila model for the Walker-Warburg syndrome. PLoS One 5: e11557.

43. Timchenko NA, lakova $P$, Cai ZJ, Smith JR, Timchenko LT (2001) Molecula basis for impaired muscle differentiation in myotonic dystrophy. Mol Cell Bio 21: $6927-6938$.

44. Apponi LH, Leung SW, Williams KR, Valentini SR, Corbett AH, et al. (2010) Loss of nuclear poly(A)-binding protein 1 causes defects in myogenesis and mRNA biogenesis. Hum Mol Genet 19: 1058-1065

45. Thurberg BL, Lynch Maloney C, Vaccaro C, Afonso K, Tsai AC, et al. (2006) Characterization of pre- and post-treatment pathology after enzyme replacement therapy for Pompe disease. Lab Invest 86: 1208-1220.

46. Strasser H, Tiefenthaler M, Steinlechner M, Bartsch G, Konwalinka G (1999) Urinary incontinence in the elderly and age-dependent apoptosis of rhabdosphincter cells. Lancet 354: 918-929.

47. Thériault ME, Paré MĖ, Maltais F, Debigaré R (2012) Satellite cells senescence in limb muscle of severe patients with COPD. PLoS One 7: e39124.

48. Han R, Campbell KP (2007) Dysferlin and muscle membrane repair. Curr Opin Cell Biol 19: 409-416.

49. Sambasivan R, Yao R, Kissenpfennig A, Van Wittenberghe L, Paldi A, et al (2011) Pax7-expressing satellite cells are indispensable for adult skeletal muscle regeneration. Development 138: 3647-3656.

50. Murphy MM, Lawson JA, Mathew SJ, Hutcheson DA, Kardon G (2011) Satellite cells, connective tissue fibroblasts and their interactions are crucial for muscle regeneration. Development 138: 3625-3637.

51. Lepper C, Partridge TA, Fan CM (2011) An absolute requirement for Pax7positive satellite cells in acute injury-induced skeletal muscle regeneration. Development 138: 3639-3646.

52. Gayraud-Morel B, Chrétien F, Flamant P, Gomès D, Zammit PS, et al. (2007) A role for the myogenic determination gene Myf5 in adult regenerative myogenesis. Dev Biol 312: 13-28

53. Mauro A (1961) Satellite cell of skeletal muscle fibers. J Biophys Biochem Cytol 9: 493-495.

54. Yablonka-Reuveni Z (2011) The skeletal muscle satellite cell: still young and fascinating at 50. J Histochem Cytochem 59: 1041-1059.

55. Collins CA, Olsen I, Zammit PS, Heslop L, Petrie A, et al. (2005) Stem cell function, self-renewal, and behavioral heterogeneity of cells from the adult muscle satellite cell niche. Cell 122: 289-301.

56. Mann CJ, Perdiguero E, Kharraz Y, Aguilar S, Pessina P, et al. (2011) Aberrant repair and fibrosis development in skeletal muscle. Skelet Muscle 1: 21

57. Carlson BM, Faulkner JA (1989) Muscle transplantation between young and old rats: age of host determines recovery. Am J Physiol 256: C1262-C1266.

58. Conboy IM, Conboy MJ, Smythe GM, Rando TA (2003) Notch-mediated restoration of regenerative potential to aged muscle. Science 302: 1575-1577.

59. Conboy IM, Conboy MJ, Wagers AJ, Girma ER, Weissman IL, et al. (2005) Rejuvenation of aged progenitor cells by exposure to a young systemic environment. Nature 433: 760-764. 
60. Conboy IM, Rando TA (2012) Heterochronic parabiosis for the study of the effects of aging on stem cells and their niches. Cell Cycle 11: 2260-2267.

61. Decary S, Hamida CB, Mouly V, Barbet JP, Hentati F, et al. (2000) Shorter telomeres in dystrophic muscle consistent with extensive regeneration in young children. Neuromuscul Disord 10: 113-120.

62. Renault V, Piron-Hamelin G, Forestier C, DiDonna S, Decary S, et al. (2000) Skeletal muscle regeneration and the mitotic clock. Exp Gerontol 35: 711-719.

63. Sacco A, Mourkioti F, Tran R, Choi J, Llewellyn M, et al. (2010) Short telomeres and stem cell exhaustion model Duchenne muscular dystrophy in $\mathrm{mdx} / \mathrm{mTR}$ mice. Cell 143: 1059-1071.

64. Rodriguez MC, Tarnopolsky MA (2003) Patients with dystrophinopathy show evidence of increased oxidative stress. Free Radic Biol Med 34: 1217-1220.

65. Gungor D, Reuser AJJ (2012) How to Describe the Clinical Spectrum in Pompe Disease?. Am J Med Gen (Part A) 9999: 1-2.

66. Kishnani PS, Corzo D, Nicolino M, Byrne B, Mandel H, et al. (2007) Recombinant human acid [alpha]-glucosidase: major clinical benefits in infantile-onset Pompe disease. Neurology 68: 99-109.

67. van der Ploeg AT, Clemens PR, Corzo D, Escolar DM, Florence J, et al. (2010) A randomized study of alglucosidase alfa in late-onset Pompe's disease. $\mathrm{N}$ Engl J Med 362: 1396-1406.

68. Manzur AY, Kuntzer T, Pike M, Swan A (2008) Glucocorticoid corticosteroids for Duchenne muscular dystrophy. Cochrane Database Syst Rev : CD003725.

69. Rüegg MA, Glass DJ (2011) Molecular mechanisms and treatment options for muscle wasting diseases. Annu Rev Pharmacol Toxicol 51: 373-395.

70. Aartsma-Rus A (2012) Overview on DMD exon skipping. Methods Mol Bio 867: 97-116.

71. Mitchell KJ, Pannérec A, Cadot B, Parlakian A, Besson V, et al. (2010) Identification and characterization of a non-satellite cell muscle resident progenitor during postnatal development. Nat Cell Biol 12: 257-266.

72. Dellavalle A, Sampaolesi M, Tonlorenzi R, Tagliafico E, Sacchetti B, et al (2007) Pericytes of human skeletal muscle are myogenic precursors distinct from satellite cells. Nat Cell Biol 9: 255-267.

73. Relaix F, Zammit PS (2012) Satellite cells are essential for skeletal muscle regeneration: the cell on the edge returns centre stage. Development 139: 2845-2856.

74. Darabi R, Arpke RW, Irion S, Dimos JT, Grskovic M, et al. (2012) Human ESand iPS-derived myogenic progenitors restore DYSTROPHIN and improve contractility upon transplantation in dystrophic mice. Cell Stem Cell 10: 610619.

75. Rocheteau P, Gayraud-Morel B, Siegl-Cachedenier I, Blasco MA, Tajbakhsh S (2012) A subpopulation of adult skeletal muscle stem cells retains all template DNA strands after cell division. Cell 148: 112-125.

76. Tedesco FS, Dellavalle A, Diaz-Manera J, Messina G, Cossu G (2010) Repairing skeletal muscle: regenerative potential of skeletal muscle stem cells. J Clin Invest 120: 11-19.

77. Usas A, Mačiulaitis J, Mačiulaitis R, Jakubonienè N, Milašius A, et al. (2011) Skeletal muscle-derived stem cells: implications for cell-mediated therapies. Medicina (Kaunas) 47: 469-479

78. Dezawa M, Ishikawa H, Itokazu Y, Yoshihara T, Hoshino M, et al. (2005) Bone marrow stromal cells generate muscle cells and repair muscle degeneration. Science 309: 314-317.

79. Feng SW, Chen F, Cao J, Yu MJ, Liang YY, et al. (2012) Restoration of muscle fibers and satellite cells after isogenic MSC transplantation with microdystrophin gene delivery. Biochem Biophys Res Commun 419: 1-6.

80. Negroni E, Riederer I, Chaouch S, Belicchi M, Razini P, et al. (2009) In vivo myogenic potential of human CD133+ muscle-derived stem cells: a quantitative study. Mol Ther 17: 1771-1778.

81. Torrente $\mathrm{Y}$, Belicchi M, Sampaolesi M, Pisati F, Meregalli M, et al. (2004) Human circulating $\mathrm{AC} 133(+)$ stem cells restore dystrophin expression and ameliorate function in dystrophic skeletal muscle. J Clin Invest 114: 182-195.

82. Tanaka KK, Hall JK, Troy AA, Cornelison DD, Majka SM, et al. (2009) Syndecan-4-expressing muscle progenitor cells in the SP engraft as satellite cells during muscle regeneration. Cell Stem Cell 4: 217-225.
83. Qu-Petersen Z, Deasy B, Jankowski R, Ikezawa M, Cummins J, et al. (2002) Identification of a novel population of muscle stem cells in mice: potential for muscle regeneration. J Cell Biol. 157: 851-864.

84. Zheng B, Cao B, Crisan M, Sun B, Li G, et al. (2007) Prospective identification of myogenic endothelial cells in human skeletal muscle. Nat Biotechnol 25 1025-1034.

85. Sampaolesi M, Blot S, D’Antona G, Granger N, Tonlorenzi R, et al. (2006) Mesoangioblast stem cells ameliorate muscle function in dystrophic dogs. Nature 444: 574-579.

86. Wen Y, Bi P, Liu W, Asakura A, Keller C, et al. (2012) Constitutive Notch activation upregulates $\mathrm{Pax} 7$ and promotes the self-renewal of skeletal muscle satellite cells. Mol Cell Biol 32: 2300-2311.

87. Beauchamp JR, Morgan JE, Pagel CN, Partridge TA (1999) Dynamics of myoblast transplantation reveal a discrete minority of precursors with stem celllike properties as the myogenic source. J Cell Biol 144: 1113-1122.

88. Qu Z, Balkir L, van Deutekom JC, Robbins PD, Pruchnic R, et al. (1998) Development of approaches to improve cell survival in myoblast transfer therapy. J Cell Biol 142: 1257-1267.

89. Patel K, Morgan J (2012) 185th ENMC International Workshop: stem/precursor cells as a therapeutic strategy for muscular dystrophies 3-5 June 2011 Naarden, The Netherlands. Neuromuscul Disord 22: 447-452.

90. De Angelis L, Berghella L, Coletta M, Lattanzi L, Zanchi M, et al. (1999) Skeleta myogenic progenitors originating from embryonic dorsal aorta coexpress endothelial and myogenic markers and contribute to postnatal muscle growth and regeneration. J Cell Biol 147: 869-878.

91. Sampaolesi M, Torrente Y, Innocenzi A, Tonlorenzi R, D'Antona G, et al. (2003) Cell therapy of alpha-sarcoglycan null dystrophic mice through intra-arterial delivery of mesoangioblasts. Science 301: 487-492.

92. Díaz-Manera J, Touvier T, Dellavalle A, Tonlorenzi R, Tedesco FS, et al. (2010) Partial dysferlin reconstitution by adult murine mesoangioblasts is sufficient fo full functional recovery in a murine model of dysferlinopathy. Cell Death Dis 1: e61.

93. Katare R, Riu F, Mitchell K, Gubernator M, Campagnolo P, et al. (2011) Transplantation of human pericyte progenitor cells improves the repair of infarcted heart through activation of an angiogenic program involving microRNA-132. Circ Res 109: 894-906.

94. Maier CL, Pober JS (2011) Human placental pericytes poorly stimulate and actively regulate allogeneic CD4 T cell responses. Arterioscler Thromb Vasc Biol 31: 183-189.

95. Meng J, Adkin CF, Xu SW, Muntoni F, Morgan JE (2011) Contribution of human muscle-derived cells to skeletal muscle regeneration in dystrophic host mice. PLoS One 6: e17454.

96. Brimah K, Ehrhardt J, Mouly V, Butler-Browne GS, Partridge TA, et al. (2004) Human muscle precursor cell regeneration in the mouse host is enhanced by growth factors. Hum Gene Ther 15: 1109-1124.

97. Montarras D, Morgan J, Collins C, Relaix F, Zaffran S, et al. (2005) Direct isolation of satellite cells for skeletal muscle regeneration. Science 309: 20642067.

98. Parker MH, Loretz C, Tyler AE, Duddy WJ, Hall JK, et al. (2012) Activation of Notch Signaling During ex vivo Expansion Maintains Donor Muscle Cell Engraftment. Stem Cells 30: 2212-2220.

99. Dahlberg A, Delaney C, Bernstein ID (2011) Ex vivo expansion of human hematopoietic stem and progenitor cells. Blood 117: 6083-6090.

100. Kuang S, Kuroda K, Le Grand F, Rudnicki MA (2007) Asymmetric self-renewal and commitment of satellite stem cells in muscle. Cell 129: 999-1010.

101. Hall JK, Banks GB, Chamberlain JS, Olwin BB (2010) Prevention of muscle aging by myofiber-associated satellite cell transplantation. Sci Transl Med 2 : $57 \mathrm{ra83}$

102. Sherwood RI, Christensen JL, Conboy IM, Conboy MJ, Rando TA, et al. (2004) Isolation of adult mouse myogenic progenitors: functional heterogeneity of cells within and engrafting skeletal muscle. Cell 119: 543-554.

103. Crist CG, Montarras D, Buckingham M (2012) Muscle Satellite Cells Are Primed for Myogenesis but Maintain Quiescence with Sequestration of Myf5 mRNA Targeted by microRNA-31 in mRNP Granules. Cell Stem Cell 11: 118126. 
104. Bjornson CR, Cheung TH, Liu L, Tripathi PV, Steeper KM, et al. (2012) Notch signaling is necessary to maintain quiescence in adult muscle stem cells. Stem Cells 30: 232-242.

105. Mourikis P, Sambasivan R, Castel D, Rocheteau P, Bizzarro V, et al. (2012) A critical requirement for notch signaling in maintenance of the quiescent skeletal muscle stem cell state. Stem Cells 30: 243-252.

106.Biressi S, Rando TA (2010) Heterogeneity in the muscle satellite cell population. Semin Cell Dev Biol 21: 845-854.

107. Ono Y, Masuda S, Nam HS, Benezra R, Miyagoe-Suzuki Y, et al. (2012) Slowdividing satellite cells retain long-term self-renewal ability in adult muscle. $J$ Cell Sci 125: 1309-1317.

108. Vella JB, Thompson SD, Bucsek MJ, Song M, Huard J (2011) Murine and human myogenic cells identified by elevated aldehyde dehydrogenase activity: implications for muscle regeneration and repair. PLoS One 6: e29226.

109. Gothot A, van der Loo JC, Clapp DW, Srour EF (1998) Cell cycle-related changes in repopulating capacity of human mobilized peripheral blood CD34(+) cells in non-obese diabetic/severe combined immune-deficient mice. Blood 92: 2641-2649.

110. Jetmore A, Plett PA, Tong X, Wolber FM, Breese R, et al. (2002) Homing efficiency, cell cycle kinetics, and survival of quiescent and cycling human CD34(+) cells transplanted into conditioned NOD/SCID recipients. Blood 99: 1585-1593.

111. Bartoszuk-Bruzzone U, Burdzińska A, Orzechowski A, Kłos Z (2012) Protective effect of sodium ascorbate on efficacy of intramuscular transplantation of autologous muscle-derived cells. Muscle Nerve 45: 32-38.

112. Kiel MJ, Yilmaz OH, Iwashita T, Yilmaz OH, Terhorst C, et al. (2005) SLAM family receptors distinguish hematopoietic stem and progenitor cells and reveal endothelial niches for stem cells. Cell 121: 1109-1121.

113. Purton LE, Scadden DT (2007) Limiting factors in murine hematopoietic stem cell assays. Cell Stem Cell 1: 263-270.

114. Kuang S, Gillespie MA, Rudnicki MA (2008) Niche regulation of muscle satellite cell self-renewal and differentiation. Cell Stem Cell 2: 22-31.

115. Vasyutina E, Lenhard DC, Wende H, Erdmann B, Epstein JA, et al. (2007) RBP-J (Rbpsuh) is essential to maintain muscle progenitor cells and to generate satellite cells. Proc Natl Acad Sci USA 104: 4443-4448.

116. Fukada S, Yamaguchi M, Kokubo H, Ogawa R, Uezumi A, et al. (2011) Hesr1 and Hesr3 are essential to generate undifferentiated quiescent satellite cells and to maintain satellite cell numbers. Development 138: 4609-4619.

117. Brack AS, Conboy MJ, Roy S, Lee M, Kuo CJ, et al. (2007) Increased Wn signaling during aging alters muscle stem cell fate and increases fibrosis. Science 317: 807-810.

118. Le Grand F, Jones AE, Seale V, Scimè A, Rudnicki MA (2009) Wnt7a activates the planar cell polarity pathway to drive the symmetric expansion of satellite stem cells. Cell Stem Cell 4: 535-547.

119. Polesskaya A, Seale $P$, Rudnicki MA (2003) Wnt signaling induces the myogenic specification of resident CD45+ adult stem cells during muscle regeneration. Cell 113: 841-852.

120. Shi X, Garry DJ (2006) Muscle stem cells in development, regeneration, and disease. Genes Dev 20: 1692-1708.

121. Latil M, Rocheteau P, Châtre L, Sanulli S, Mémet S, et al. (2012) Skeleta muscle stem cells adopt a dormant cell state post mortem and retain regenerative capacity. Nat Commun 3: 903.

122. Morrison SJ, Csete M, Groves AK, Melega W, Wold B, et al. (2000) Culture in reduced levels of oxygen promotes clonogenic sympathoadrenal differentiation by isolated neural crest stem cells. J Neurosci 20: 7370-7376.

123. Studer L, Csete M, Lee SH, Kabbani N, Walikonis J, et al. (2000) Enhanced proliferation, survival, and dopaminergic differentiation of CNS precursors in lowered oxygen. J Neurosci 20: 7377-7383.

124. Yoshida Y, Takahashi K, Okita K, Ichisaka T, Yamanaka S (2009) Hypoxia enhances the generation of induced pluripotent stem cells. Cell Stem Cell 5: 237-241.

125. Di Carlo A, De Mori R, Martelli F, Pompilio G, Capogrossi MC, et al. (2004) Hypoxia inhibits myogenic differentiation through accelerated MyoD degradation. J Biol Chem 279: 16332-16338.
126. Gustafsson MV, Zheng X, Pereira T, Gradin K, Jin S, et al. (2005) Hypoxia requires notch signaling to maintain the undifferentiated cell state. Dev Cell 9: 617-628

127. Liu W, Wen Y, Bi P, Lai X, Liu XS, et al. (2012) Hypoxia promotes satellite cell self-renewal and enhances the efficiency of myoblast transplantation. Development 139: 2857-2865

128. Koning M, Werker PM, van Luyn MJ, Harmsen MC (2011) Hypoxia promotes proliferation of human myogenic satellite cells: a potential benefactor in tissue engineering of skeletal muscle. Tissue Eng Part A 17: 1747-1758.

129. Tilkorn DJ, Davies EM, Keramidaris E, Dingle AM, Gerrand YW, et al. (2012) The in vitro preconditioning of myoblasts to enhance subsequent survival in an in vivo tissue engineering chamber model. Biomaterials 33: 3868-3879.

130.Bandyopadhyay A, Dong Q, Sun LZ (2012) Stem/Progenitor cells in murine mammary gland: isolation and functional characterization. Methods Mol Bio 879: $179-193$

131.Fogel J, Znamensky V (2012) Cardiosphere-derived cells for heart regeneration. Lancet 379: 2426.

132. Mimura T, Yamagami S, Yokoo S, Usui T, Amano S (2010) Selective isolation of young cells from human corneal endothelium by the sphere-forming assay. Tissue Eng Part C Methods 16: 803-812.

133. Galli R, Gritti A, Bonfanti L, Vescovi AL (2003) Neural stem cells: an overview. Circ Res 92: 598-608.

134. Sarig R, Baruchi Z, Fuchs O, Nudel U, Yaffe D (2006) Regeneration and transdifferentiation potential of muscle-derived stem cells propagated as myospheres. Stem Cells 24: 1769-1778.

135. Wei Y, Li Y, Chen C, Stoelzel K, Kaufmann AM, et al. (2011) Human skeletal muscle-derived stem cells retain stem cell properties after expansion in myosphere culture. Exp Cell Res 317: 1016-1027.

136. Westerman KA, Penvose A, Yang Z, Allen PD, Vacanti CA (2010) Adult muscle 'stem' cells can be sustained in culture as free-floating myospheres. Exp Cell Res 316: 1966-1976.

137. Shea KL, Xiang W, LaPorta VS, Licht JD, Keller C, et al. (2010) Sprouty1 regulates reversible quiescence of a self-renewing adult muscle stem cell poo during regeneration. Cell Stem Cell 6: 117-129.

138. Nagata Y, Kobayashi H, Umeda M, Ohta N, Kawashima S, et al. (2006) Sphingomyelin levels in the plasma membrane correlate with the activation state of muscle satellite cells. J Histochem Cytochem 54: 375-384.

139. Tatsumi R, Liu X, Pulido A, Morales M, Sakata T, et al. (2006) Satellite cell activation in stretched skeletal muscle and the role of nitric oxide and hepatocyte growth factor. Am J Physiol Cell Physiol 290: C1487-C1494.

140. Mouly V, Aamiri A, Périé S, Mamchaoui K, Barani A, et al. (2005) Myoblast transfer therapy: is there any light at the end of the tunnel? Acta Myol 24 128-133.

141. Kandalla PK, Goldspink G, Butler-Browne G, Mouly V (2011) Mechano Growth Factor $E$ peptide (MGF-E), derived from an isoform of IGF-1, activates human muscle progenitor cells and induces an increase in their fusion potential at different ages. Mech Ageing Dev 132: 154-162.

142. McFarlane C, Hui GZ, Amanda WZ, Lau HY, Lokireddy S, et al. (2011) Human myostatin negatively regulates human myoblast growth and differentiation. Am J Physiol Cell Physiol 301: C195-C203.

143. Burdzińska A, Bartoszuk-Bruzzone U, Godlewski MM, Orzechowski A (2006) Sodium ascorbate and basic fibroblast growth factor protect muscle-derived cells from H2O2-induced oxidative stress. Comp Med 56: 493-501.

144.Engler AJ, Griffin MA, Sen S, Bönnemann CG, Sweeney HL, et al. (2004) Myotubes differentiate optimally on substrates with tissue-like stiffness: pathological implications for soft or stiff microenvironments. J Cell Biol 166: 877-887.

145. Takahashi K, Tanabe K, Ohnuki M, Narita M, Ichisaka T, et al. (2007) Induction of pluripotent stem cells from adult human fibroblasts by defined factors. Cell 131: $861-872$

146. Takahashi K, Yamanaka S (2006) Induction of pluripotent stem cells from mouse embryonic and adult fibroblast cultures by defined factors. Cell 126 $663-676$ 
Citation: Schaaf G, Sage F, Stok M, Brusse E, Pijnappel WWM, et al. (2012) Ex-vivo Expansion of Muscle-Regenerative Cells for the Treatment of Muscle Disorders. J Stem Cell Res Ther S11:003. doi:10.4172/2157-7633.S11-003

147. Soldner F, Hockemeyer D, Beard C, Gao Q, Bell GW, et al. (2009) Parkinson's disease patient-derived induced pluripotent stem cells free of viral reprogramming factors. Cell 136: 964-977.

148. Nishimura K, Sano M, Ohtaka M, Furuta B, Umemura Y, et al. (2011) Development of defective and persistent Sendai virus vector: a unique gene delivery/expression system ideal for cell reprogramming. J Biol Chem 286: 4760-4771.

149. Barberi T, Bradbury M, Dincer Z, Panagiotakos G, Socci ND, et al. (2007) Derivation of engraftable skeletal myoblasts from human embryonic stem cells. Nat Med 13: 642-648.

150. Mahmood A, Harkness L, Schrøder HD, Abdallah BM, Kassem M (2010) Enhanced differentiation of human embryonic stem cells to mesenchymal progenitors by inhibition of TGF-beta/activin/nodal signaling using SB-431542. J Bone Miner Res 25: 1216-1233.

151. Mizuno Y, Chang H, Umeda K, Niwa A, Iwasa T, et al. (2010) Generation of skeletal muscle stem/progenitor cells from murine induced pluripotent stem cells. FASEB J 24: 2245-2253.

152. Quattrocelli M, Palazzolo G, Floris G, Schöffski P, Anastasia L, et al. (2011) Intrinsic cell memory reinforces myogenic commitment of pericyte-derived iPSCs. J Pathol 223: 593-603.

153. Sakurai H, Inami Y, Tamamura Y, Yoshikai T, Sehara-Fujisawa A, et al. (2009) Bidirectional induction toward paraxial mesodermal derivatives from mouse ES cells in chemically defined medium. Stem Cell Res 3: 157-169.

154.Zheng JK, Wang Y, Karandikar A, Wang Q, Gai H, et al. (2006) Skeletal myogenesis by human embryonic stem cells. Cell Res 16: 713-722.

155.Darabi R, Gehlbach K, Bachoo RM, Kamath S, Osawa M, et al. (2008)
Functional skeletal muscle regeneration from differentiating embryonic stem cells. Nat Med 14: 134-143.

156. Darabi R, Santos FN, Filareto A, Pan W, Koene R, et al. (2011) Assessment of the myogenic stem cell compartment following transplantation of Pax3/Pax7induced embryonic stem cell-derived progenitors. Stem Cells 29: 777-790.

157. Boldrin L, Muntoni F, Morgan JE (2010) Are human and mouse satellite cells really the same? J Histochem Cytochem 58: 941-955.

158. Ehrhardt J, Brimah K, Adkin C, Partridge T, Morgan J (2007) Human muscle precursor cells give rise to functional satellite cells in vivo. Neuromuscul Disord 17: 631-638.

159. Abou-Khalil R, Le Grand F, Pallafacchina G, Valable S, Authier FJ, et al (2009) Autocrine and paracrine angiopoietin 1/Tie-2 signaling promotes muscle satellite cell self-renewal. Cell Stem Cell 5: 298-309.

160. Yoshida N, Yoshida S, Koishi K, Masuda K, Nabeshima Y (1998) Cel heterogeneity upon myogenic differentiation: down-regulation of MyoD and Myf-5 generates 'reserve cells'. J Cell Sci 111: 769-779.

161. Brehm MA, Shultz LD, Greiner DL (2010) Humanized mouse models to study human diseases. Curr Opin Endocrinol Diabetes Obes 17: 120-125.

162. Yaffe D, Saxel O (1977) A myogenic cell line with altered serum requirements for differentiation. Differentiation 7: 159-166.

163. Deasy BM, Gharaibeh BM, Pollett JB, Jones MM, Lucas MA, et al. (2005) Long-term self-renewal of postnatal muscle-derived stem cells. Mol Biol Cell 16: 3323-3333.

164. Morgan JE, Zammit PS (2010) Direct effects of the pathogenic mutation on satellite cell function in muscular dystrophy. Exp Cell Res 316: 3100-3108.

This article was originally published in a special issue, Muscle Stem Cells handled by Editor(s). Dr. Stefano Biressi, Stanford University, USA; Dr. Atsushi Asakura, University of Minnesota Medical School, USA 